\title{
To Do a Work that Would Be Very Far Reaching: Minnie Geddings Cox, the Mississippi Life Insurance Company, and the Challenges of Black Women's Business Leadership in the Early Twentieth-Century United States
}

\author{
SHENNETTE GARRETT-SCOTT
}

In early December 1923 in Memphis, Tennessee, Minnie Geddings Cox sat in a hastily arranged board meeting across from Heman Perry, clear now that the man she had believed her advocate was most assuredly her adversary. Cox and Perry, a man Forbes magazine would describe in 1924 as the richest Negro in the world, spent nearly a year maneuvering a merger to join her company, Mississippi Life Insurance Company, the third largest black-owned life insurance company in the United States, with his Standard Life of Atlanta, which ranked second. ${ }^{1}$ They shared a vision to create the largest black-owned life insurance company in the United States-or so Cox thought.

(c) The Author 2016. Published by Cambridge University Press on behalf of the Business History Conference.

doi:10.1017/eso.2015.66

Published online May 2, 2016

Shennette GARRETT-ScotT is assistant professor of History and African-American Studies at University of Mississippi and is currently at work on her book manuscript, Invincible Daughters of Commerce: Black Women in Finance, 1890s to 1950s. Contact information: University of Mississippi, Dept of African American Studies, 304 Longstreet Hall, P.O. Box 1848, University, Mississippi, United States, 38677-1848. Email: smgscott@olemiss.edu.

I appreciate funding from the 2012-2013 Case Western Reserve University Postdoctoral Fellowship in African-American Studies to complete research for this article. I also wish to thank Delta Women Writers, Rhonda Y. Williams, Allison Dorsey, Jen Barclay, Ariana Alexander, Gregg F. Stewart, and the anonymous reviewers for insightful comments on this work.

1. Forbes estimated that Perry was worth $\$ 8$ million (or about $\$ 111$ million in 2015 dollars). Eric C. Walrond, "Largest Negro Commercial Enterprise in the World,” Forbes (February 2, 1924), reprinted in Lerone Bennett Jr., "The Making of Black America, Part 11. The Quest for Economic Security,” Ebony (February, 1974), 74-75. All 2015 dollar figures from U.S. Government's Consumer Price Index inflation calculator at http://data.bls.gov/cgi-bin/cpicalc.pl (accessed April 1, 2015). 
The forces that drew together Cox and Perry at that wooden conference table in Memphis were greater than either of them could have imagined. Insurance companies like Cox and Perry's built their fortunes providing products and services to an almost exclusively black clientele. Beginning in the early 1880s, white-owned insurance companies cited what they claimed were scientific, neutral, and objective measures of diseased, inferior, and degenerate black bodies. They ignored social and economic factors such as poverty and segregation and scientists' inherent racist biases to argue blacks were not only inherently inferior in vitality but also prone to social and physical diseases. They then relied on such science to justify charging higher rates, reducing benefits, and denying coverage altogether. Ironically, by the 1920s, many of the same companies coveted the client base of black companies, though notions of black inferiority and degeneracy persisted.

Successes like Cox and Perry's had also raised the hackles of state insurance commissioners, who sometimes colluded with white-owned insurance companies to exert various forms of legal pressure and bureaucratic intimidation. Commissioners bullied and, in many cases, dismantled black-owned insurance companies and other financial organizations that lay within their regulatory reach. Reform-minded politicians and regulators compelled the state to protect legitimate social institutions. Too often, however, they narrowly defined legitimate institutions. Though some companies were certainly in need of reform, the state responded in ways that treated blacks' economic and political agency, especially building financial institutions, as a threat to, rather than a model of, the possibilities of democracy and economic opportunity.

In addition to the external pressures of aggressive competition and rapacious regulation, practical and personal matters dogged Cox and Perry. Corporate fraud and mismanagement as well as personal ambition and rivalries underlay conflicting motives for their merger. Together, all of these forces undermined Cox's vision to create the largest black-owned insurance company in the United States. It also led to the rapid demise of both Cox's and Perry's companies.

Minnie Geddings Cox faced considerable challenges in building and maintaining a successful insurance company. Uncovering her experiences involves considerable challenges as well. The lack of business records and personal correspondence force a reliance on other records, such as census data, newspapers, biographies, and other published primary source material. These materials cannot convey a complete picture, particularly the thoughts, feeling, and motivations of key actors. A full financial picture of the company also eludes even the most determined scholar. However, it is imperative to reconstruct stories like Cox's that have been marginalized in large part because of the paucity of sources. 
In building and maintaining a successful insurance company, Cox shared the experiences of other business owners, regardless of race or sex. She had to create and implement a marketing and growth strategy, stay abreast of trends and developments in the industry, and hire and manage employees. She also had to work with a board of directors, shareholders, company officials, and customers. She stayed apprised of regulations in the industry, filed state reports, and paid taxes and fees.

In other ways, race, gender, and class intersected to work to her advantage and disadvantage. Because of her race, she faced considerable challenges in building a successful business. Cox lived and worked in Mississippi, "the most southern place on earth,"2 a place where the siren song of New South rhetoric stressed inclusion in a national (and global) drive for U.S. economic ascendancy at the same time it crystallized racial hierarchies. Blacks lacked adequate access to capital, credit, and training, which not only hampered their ability to compete but also left them vulnerable to corruption and mismanagement. Threats and actual instances of violence also underscored efforts to keep blacks' ambitions in check.

However, because of race, the insurance industry excluded a broad swath of potential clients and created an underserved market. Fraternal insurance initially filled the gap, and its success led to the creation of insurance companies. These companies appealed to race pride and positioned their businesses as tangible evidence of black self-help, uplift, and progress.

Cox's gender added another layer of complexity. She strived in an industry that positioned women as dependents in dire need of the protections that insurance products offered. Women were not imagined as either the proper producers or consumers of insurance products. In addition, her leadership over and the power she exercised in a corporation were unusual for a woman: black or otherwise, inside or outside of the insurance industry. The early twentieth-century notion of captains of industry invoked a masculine image of "legitimate"and preferred-leadership in the business community. However, she placed trusted male advisors in key positions, which allowed her to appear removed from the main workings of power.

Class, too, presented challenges and opportunities for Cox. Black insurance companies acted with profits in mind; they were sometimes accused-and often justifiably so-of preying on the lower classes. Poor- and working-class customers sometimes could not afford to keep up with their payments, even though they were

2. Description from Cobb, The Most Southern Place on Earth: The Mississippi Delta and the Roots of Southern Identity (New York; Oxford: Oxford University Press, 1993). 
only a few cents a week. Many were illiterate and sometimes cheated out of their rightful benefits. However, Cox also promoted men and especially women who would have worked in fields and kitchens to white-collar jobs, but she did not hesitate to deny sharecroppers and domestics benefits if the company could. Finally, blacks who appeared too successful could incur the wrath of jealous whites.

The 1923 encounter between Cox and Perry then represented a nexus of race, gender, and class within early twentieth century U.S. capitalism but also in the black separate economy. Cox, forced to operate at the margins of the insurance industry, met the challenge and created a successful company. Her experiences with Mississippi Life reflect the limits and possibilities of black female corporate leadership at the turn of the twentieth century.

\section{A Monument of Protest: Origins of the Mississippi Life Insurance Company}

Minnie M. Geddings was born in the small town of Lexington, Holmes County, Mississippi, in 1869 to former slaves William and Mary (or Elizabeth) Geddings. Few details exist about her early life, though it appears she lived a life of some privilege compared to most other blacks living in the Mississippi Delta. ${ }^{3}$ Her parents owned a restaurant. Cox attended Fisk University in Nashville, Tennessee, graduating from its normal school program around 1888. As part of one of the largest cohorts of women (over 100) attending Fisk in the period, Cox imbibed not just an industrial education but also a sense of the leadership potential of educated black women. ${ }^{4}$ She returned

3. For works discussing the racial, political, and economic climate of the Mississippi Delta in the late nineteenth and early twentieth centuries, see Ibid.; McMillen, Dark Journey; and Woodruff, American Congo.

4. Biographical information from Elizabeth Gedding [sic] in household of Wayne W. Cox, Indianola, Sunflower, Mississippi, “U.S. Census, 1910,” index and images, FamilySearch, https://familysearch.org/pal:/MM9.1.1/MPDP-TZP (accessed January 29, 2014); marriage date from W. W. Cox and Minnie Geddings, 1889, “Mississippi, Marriages, 1800-1911,” index, FamilySearch, URL: https:// familysearch.org/pal:/MM9.1.1/V2ZZ-F1B (accessed January 29, 2014); "W. W. Cox," Beacon Lights, 225; "Wayne and Minnie Cox, Sunflower County, Privately Funded [State Historical Marker Narrative]" and "Programme, Dedication Ceremonies. Wayne and Minnie Cox Park. 10 am, February 21, 2004 Sunflower County Courthouse, Indianola, Mississippi," both in Subject File: Cox, Minnie, in Mississippi Department of Archives and History, Jackson, Mississippi [archive hereafter MDAH]; and Tucker, Lieutenant Lee, 3-4. Reference to Geddings' restaurant in Steven J. Niven, "Cox, Minnie," in African American National Biography (accessed January 29, 2014). On "Fisk Women" in the late nineteenth century, see Pethel, "Athens of the South,” 178-181. I appreciate Rebecca Tuuri for bringing Pethel's work on late nineteenth century Fisk women to my attention. 
to Mississippi and taught at the new colored public school in Indianola. Cox's future husband, Wayne Wellington Cox, worked there as principal. In Minnie, Wayne found a woman equal to his ambitions; his future wife purchased the first of her significant real estate holdings a year before they married in October 1889. The couple had one daughter, Ethyl. ${ }^{5}$

In 1891, Republican President Benjamin Harrison appointed Cox postmistress of Holmes County, making her the first black woman postmaster in Mississippi. ${ }^{6}$ However, around 1902, whites in the Delta-roiled by the combination of a severe drop in cotton prices, attempts by President Theodore Roosevelt to strengthen the southern wing of the Republican Party, and an aggressive political contest for governor-channeled their frustrations onto blacks. Cox found herself caught in the crosshairs. Cox's college education, land and property holdings, civil servant position, and comfortable salary placed her at the center of white resentment and made her a target of violence. In December 1902, after several months of threats and provocations, Cox resigned as postmistress and refused to return to the Indianola Post Office. She and her family fled Indianola.

President Theodore Roosevelt refused to accept her resignation and closed the post office. Newspapers from the period referred to incident as the "Indianola Affair." The Indianola Affair sparked the first major national debate about race, states' rights, and federal power since Reconstruction, making Cox a minor footnote in contemporary history textbooks. However, her experiences during the affair shaped her philosophy of building businesses and wealth and inspired other enterprising blacks. ${ }^{7}$ After spending more than a year in exile in

5. On Cox landholdings, two parcels to M. M. Geddings for $\$ 500$ on November 15, 1888, recorded on July 1, 1890, in Deed Records, Book M, Page 69, Sunflower County, Chancery Clerk's Office [office hereafter sccco]. In addition to a large plantation, Cox also owned several rental homes and other improved property in and around Indianola. See multiple real estate transactions in Chancery Court records and land ownership of plantation mentioned in "Petition to Be Allowed to Finish Furnish[ing] Contractors, Manage Crops, Etc.,” Filed May 17, 1916, in Probate Records, Estate of Wayne W. Cox, Minnie M. Cox, Executrix, File 2812 [hereafter wwc Probate Records] (sccco).

6. Cox was not the first black postmistress as many sources claim. See Rubio, There's Always Work, 174 and Historian U.S. Postal Service, "African American Postal Workers in the 19th Century," http://about.usps.com/who-weare/postal-history/african-american-workers-19thc-2011.rtf (accessed April 1, 2015).

7. For conventional treatments of the Indianola Affair that focus either on James K. Vardaman's election under Mississippi’s new direct primary system in 1902, the limitations of two-party politics in the early twentieth-century South, or debates about how "progressive" Roosevelt was on the question of race see, Mowry, "South and Progressive”; De Santis, "Republican Party"; Scheiner, "President Theodore Roosevelt”; and Gatewood, "Theodore Roosevelt." 
Birmingham, the Coxes returned to Indianola in early 1904. By late 1904, they organized the second black-owned bank in the state, the Delta Penny Savings Bank, which opened for business in early $1905 .^{8}$ The Coxes organized the Mississippi Beneficial Life Insurance Company a few years later, in 1908.

The Delta Penny and Mississippi Life were hardly alone. Hundreds of other black-owned businesses sprang up throughout Mississippi in the early 1900s. Indeed, tens of thousands of blackowned businesses throughout the country ushered in what Juliet E. K. Walker has described as the "Golden Age of Black Business."9 The growth of the black group economy, businesses owned by blacks focused on an exclusively black clientele, represented more than a capitulation to segregation. ${ }^{10}$ They represented a practical riposte to Jim Crow, a system of laws and customs that blocked blacks' ambition and progress through segregation and discrimination, denial of education and civil rights, economic repression, and violence. ${ }^{11}$ Wayne Cox described the Delta Penny, Mississippi Life, and other black-owned businesses in the state as "monuments of protest to the injustices inflicted upon him and his wife" during the Indianola Affair. ${ }^{12}$ His sentiment expressed that blacks refused to operate at the margins of the Jim Crowed economy and would

8. "Charter of Incorporation of the Delta Penny Savings Bank," dated October 29, 1904, filed November 8, 1904, Deed Record Book T2, Page 142 (sccco); and opening in "W. W. Cox," Beacon Lights, 219.

9. Walker, "Golden Age of Black Business, 1900-1930," in The History of Black Business, 182-224.

10. The black group economy was never completely separate from the mainstream economy. Some whites used the services of black-owned businesses, and black consumers certainly utilized the services of non-black merchants. If the National Negro Business League is an accurate barometer, black business owners remained divided about the efficacy of pursuing and maintaining a black-only clientele. They debated the problems faced by black business. Some rejected outright a complete reliance on black consumers while others rejected any assistance from whites-as customers or partners.

11. On early Jim Crow, see Edward Ayers, The Promise of the New South: Life After Reconstruction (New York; Oxford: Oxford University Press, 1992); Glenda Gilmore, Gender and Jim Crow: Women and the Politics of White Supremacy in North Carolina, 1896-1920 (Chapel Hill: University of North Carolina Press, 1996); Leon F. Litwack, Trouble in Mind: Black Southerners in the Age of Jim Crow (New York: Vintage Books, 1998); and C. Vann Woodward, The Strange Career of Jim Crow: A Commemorative Edition (New York; Oxford: Oxford University Press, 2002). On Jim Crow in Mississippi, see McMillen, Dark Journey and Woodruff, American Congo.

12. Quote in Stuart, An Economic Detour, 302. Some years later, Wayne Cox made a more explicit connection between the Indianola Affair and he and his wife's decision to create the Delta Penny Savings Bank: "We had a little post-office trouble down there in 1903, and it is my pleasure tell you that we started a Negro bank with $\$ 16,000$ subscribed in stock." See comments in Report of the Eleventh Annual Convention, 181. 
create businesses and economic opportunities for themselves and others.

Minnie Cox's business experiences reinforce what scholars already know about the difficulties of living within the political economy of the Jim Crow Delta. ${ }^{13}$ They also contribute to and challenge what we know about black business and activism in the "First New South," the period from 1865 to $1920 .{ }^{14}$ Blacks in general and black women in particular negotiated a deep set of contradictions. They confronted conflicting messages about their place in this "new" South. Caught between optimistic New South ideology and brutal Jim Crow reality, business provided an effective but very often problematic strategy for dealing with social and economic changes in the late nineteenth and early twentieth century New South. Despite assurances by Booker T. Washington and the optimism expressed by other "Negro captains of industry," a coterie of successful, influential, self-made men charged with the double duty of creating wealth and social prosperity in the black community while fulfilling political and cultural obligations to it, a straight line did not proceed from the growth of the black group economy to peaceful racial relations and a progressive business climate.

In addition, captains of industry invoked a decidedly masculine image of black business leadership. When passionate advocates talked about the importance of successful businessmen as the keystone of black economic, social, and political progress, they meant businessmen. In particular, the insurance industry relied on genderinfused rhetoric that promoted masculine responsibility and duty for dependent and vulnerable women, rhetoric that rendered women the objects of protection and men the ideal producers and consumers of insurance products. Black women certainly challenged such constructions of their role in the industry. Indeed, businesswomen like Cox and others challenged male bodies as the legitimate-and preferred-leaders in the black business community and in the insurance industry.

However, Cox was not a typical black businesswoman. Unlike her contemporaries in the industry, particularly Maggie Lena Walker of the Independent Order of Saint Luke in Richmond, Virginia, Cox does not fit comfortably in well-elaborated histories of "Sable Victorians": women who shaped and mobilized a politics of respectability through reform, community and social-service institutions,

13. On early Jim Crow, see Ayers, Promise of the New South; Gilmore, Gender and Jim Crow; Litwack, Trouble in Mind; and Woodward, Strange Career. On Jim Crow in Mississippi, see McMillen, Dark Journey and Woodruff, American Congo.

14. Reference to Rabinowitz, First New South. 
and conventional comportment. ${ }^{15}$ More sustained focus on black women's entrepreneurial activities brings to the fore what scholars have too often treated as peripheral and negligible elements of black political and social struggles. Entrepreneurship provides a means to understand the many ways blacks have struggled to strike a tenable balance between personal agency and structural constraints. It also provides a way to reconfigure black women's participation in the economy, nation building, and politics.

\section{Negro Wizards of Insurance: The Development of the Black Insurance Industry}

In the decades after the Civil War, blacks contributed to the growing popularity of industrial insurance. Industrial insurance policies were marketed primarily to wage workers. They provided modest benefits on death for small, weekly premiums of a few cents. ${ }^{16}$ They duplicated similar types of insurance, sometimes called endowment insurance, offered by fraternals, or secret societies. ${ }^{17}$ Large companies like Prudential and Metropolitan Life counted blacks among their clients. Blacks paid more for these policies than whites, sometimes as much as three times more if they worked in hazardous occupations, largely because insurance companies routinely charged higher rates on black lives in slave insurance policies. ${ }^{18}$

In 1881, Prudential turned to statistical studies of higher black mortality rather than impartial or traditional practices to set premium rates. The company argued that increased risk justified raising

15. On Maggie Lena Walker, see Elsa Barkley Brown, "Uncle Ned’s Children" Negotiating Community and Freedom in Postemancipation Richmond, Virginia" (Ph.D. Diss., Kent State University, 1994); Garrett-Scott, "Daughters of Ruth," 120-183 and 295-301; and Gertrude W. Marlowe, A Right Worthy Grand Mission. Maggie Lena Walker and the Quest for African American Economic Empowerment.

16. For an overview of black insurance since the sixteenth century to the Civil War era, see Garrett-Scott, "Daughters of Ruth," 49-65.

17. The Ancient Order of United Workmen (AOUw), organized in 1868, is considered the first society in the United States to develop a viable fraternal insurance plan. In 1869, the Aouw instituted its fraternal insurance or endowment plan. In 1873, the Aouw organized its women's auxiliary, the Decree of Honor. Prudential Insurance found success with industrial insurance where other companies had failed. The company, which started as Prudential Friendly Society in 1875, offered industrial workers policies modeled on fraternal insurance. For as low as three cents and up to twenty-five cents a week, the policies paid a small benefit that covered modest funeral expenses and left a small amount for designated beneficiaries. The society became Prudential Insurance Company of America in 1877. Bayse, History and Operation, 9-12; Hoffman, History of the Prudential, 55-58, 71-72.

18. Agesa, Agesa, and Berry, "A History of Racial Exploitation." 
premium rates, cutting benefits, and, in some cases, denying benefits altogether. Higher black mortality was not a fallacy. However, the emerging field of actuarial science capitalized on a growing body of statistical evidence and on racist, eugenic pseudoscience to justify stripping blacks of their benefits. For example, in his 1896 work Race Traits and Tendencies of the American Negro, Frederick Hoffman, a pioneer in actuarial science and a staunch white supremacist, warned clients like Metropolitan Life that blacks were on the road to extinction, based not on "sentiment, prejudice, or the influence of pre-conceived ideas," he asserted, but hard science. ${ }^{19}$ These allegedly scientific, neutral, and objective measures ignored social, political, and economic factors such as racist discourses, segregation, and poverty to "prove" that blacks were not only fundamentally inferior in vitality but also inherently prone to social and physical diseases.

By the early twentieth century, mortality tables such as the Glover Life Tables relied on cherry-picked census data to substantiate startling disparities in black and white mortality rates. Some figures reported black death rates that were twice and even treble the rates for whites. Increasingly throughout the twentieth century, the insurance industry and other kinds of social services and programs relied on actuarial science and other applied social sciences, arguing that scientific bases rather than racial sentiment justified the exclusion or disparate treatment of blacks. ${ }^{20}$

In addition to scientific narratives, industry professionals also exercised social pressure to treat African-American clients differently. In 1903, an anonymous agent in Beekman, New York, wrote that a number of "superior Negroes" had approached him for insurance, but the agent's company refused to insure them. The editor responded, "I do not know of any reputable company which writes negro risks, save with very great caution. Such companies as the Mutual Reserve and others of the off-color sort, write them freely, or used to do so."21 Within their professional networks, insurance professionals maligned

19. Frederick L. Hoffman, Race Traits and Tendencies of the American Negro, Publications of the American Economic Association, Volume 11 (New York: American Economic Association; Macmillan, 1896), 311, URL: http://books.google. com/books?id=8L84AAAAIAAJ.

20. See the Glover Life Tables in Crum, "White and Colored." Several works have noted racist notions of racial fitness in actuarial science extending to commercial and residential mortgage loan underwriting, prison management, and social welfare programs. See, Agesa, et al, "A History of Racial Exploitation”; Bouk, "The Science of Difference"; Crossney and Bartelt, "Residential Security"; Horan, "Actuarial Age"; Lawrie, "Mortality as the Life Story"; and Wiggins, "Managing Risk, Managing Race.” For alternate visions of racial destiny in African American intellectual and vernacular history, see Mitchell, Righteous Propagation.

21. Letter, The Life Insurance Independent and American Journal of Life Insurance 15 (November 1903): 219-220, quote on 220. 
companies that underwrote black risks and exercised social pressure to keep agents and their companies from insuring black clients.

As major insurance companies dropped and shunned black clients, black-owned insurance companies filled the void-but not immediately. Around the same time that John Dryden experimented with the Prudential Friendly Society, pioneers like William W. Browne of the Grand Fountain of the United Order of True Reformers and Thomas Stringer of the Colored Masons and Colored Knights of Pythias created new models of fraternal insurance within black secret societies. ${ }^{22}$ These models borrowed elements from society's like Dryden's, such as classes of risk based on age. They also capitalized on longstanding features of black secret societies, such as their conviviality, orientation toward self-help, and secrecy.

As racial hierarchies hardened in early twentieth century US culture, economy, and society, these societies also served as circuits of capital for black businesses, loans, and mortgages. The bureaucratic administration, by-laws, and hierarchical leadership associated with running a fraternal insurance business provided unmatched opportunities for business education, training, and leadership. Coupled with their mystery, ritual, and sociability, blacks carved out a space to enact civil and economic rights denied them in larger society. Thousands of secret societies, mutual organizations, and related groups sprang up in black communities from the 1870s to World War I. ${ }^{23}$

However, fraternal insurance presented its own challenges. Policies offered limited benefits; it was not unusual for an individual to own several different policies with as many societies. Corruption and mismanagement were not uncommon. Customers longed for more anonymity; they desired the financial benefits without the need for secret handshakes and passwords, the numerous fees associated with

22. William Washington Brown is instructive. In the late 1860 s or early 1870 s, former slave Browne joined a segregated local of the Order of Templars, a temperance society. In 1873, when Browne sought an administrative position in the Order of Templars, the leaders encouraged Browne to join its mirror organization that shared the principles and goals of the Templars-but not its name. He organized the Grand Fountain of the United Order of True Reformers in 1875 in a small Alabama town. He reorganized the society in 1881 and headquartered it in the more progressive New South city of Richmond. At its height, the True Reformers operated a savings bank, real estate company, retirement home, newspaper, and store in Richmond and boasted. On Browne, see W. W. Browne and D. Webster Davis, The Life and Public Services of Rev. William Washington Browne (Philadelphia: The AME Book Concern, Printers and Publishers, 1910) and David M. Fahey, ed., The Black Lodge in White America: "True Reformer" Browne and His Economic Strategy (Dayton, Oh.: Wright State University, 1994).

23. On black fraternal insurance, see Beito, From Mutual Aid; and Garrett-Scott, "Daughters of Ruth," 46-83. 
membership, or the internal jealousies and social jockeying that often emerged in these societies.

It was not until the 1890s that black-owned stock and mutual insurance companies formed. Ironically, most grew out of the disintegration of the True Reformers. As the True Reformers became more and more successful, Browne grew more suspicious of those in power around him. Many high-ranking True Reformers left and formed their own fraternal insurance organizations and formal insurance companies. Booker L. Jordan, former general manager of the True Reformers' Mercantile Department, co-founded the first chartered black insurance company, the Southern Aid Society, in Richmond, Virginia, in 1893. ${ }^{24}$ The number of insurance companies continued to grow.

\section{Mississippi Life, 1908-1916}

In 1908, Wayne and Minnie Cox joined these growing numbers of insurance companies when they opened the Mississippi Beneficial Life Insurance Company, the first black-owned insurance company in Mississippi. Their decision was a bold one, driven by their ambition to create "monuments of protest" after what they had suffered during the Indianola Affair. In 1910, Mississippi Life took an even more momentous step: It became the first black-owned company to offer whole life insurance benefits. ${ }^{25}$

Secret societies enjoyed a monopoly on insuring blacks in Mississippi. Secret societies proliferated because they required little upfront investment and were subjected to minimal regulatory oversight before the early 1910s. The most popular groups in Mississippi-and stiff competition for Mississippi Life-included the Masonic Benefit Society, Knights and Daughters of Tabor, and Odd Fellows. In 1909, for example, no fewer than 46 black secret societies held licenses to

24. Burrell, "The Negro in Insurance."

25. The Mississippi Beneficial Life Insurance Company was the first chartered and operating black-owned legal reserve insurance company; it changed its name to Mississippi Life Insurance Company in 1920. I will use Mississippi Life to stand in for both names. In 1913, North Carolina Mutual (NCMIC) raised the $\$ 100,000$ reserve requirement and changed its charter, making it the second chartered black-owned legal reserve insurer. Standard Life of Atlanta, under the direction of Heman Perry, became the third in March 1913. Some scholars note that NCM was the first to operate as a legal reserve insurance company, but Attaway's comments at the National Negro Business League meeting in 1910 reveal that Mississippi Life offered some whole life products to Afro-Mississippians soon after changing its charter in 1910. On founding of Mississippi Life, see "Cox, Wayne Wellington," Who's Who, 79; and "W. W. Cox," Beacon Lights, 222. See Attaway's comments in W. A. Attaway, "Mutual Benefit Insurance," Report of the Eleventh Annual Convention, 105-106. 
do business in the state. None of the established black-owned insurance companies in the country operated in Mississippi, and none of them offered whole life insurance. ${ }^{26}$ The decision to offer whole life, when no other black-owned company offered such products, was a bold and ambitious move on the part of Mississippi Life's board.

Wayne Cox and Dr. William Attaway undoubtedly pushed the board to make such a bold move. As Supreme Secretary-Treasurer of the Woodmen of Union, Wayne had first-hand knowledge of the financial success and popularity of fraternal insurance. As a practicing physician, Attaway was also aware of the financial benefits. Attaway studied the available literature and taught himself the insurance business; contemporaries characterized him as "the Negro Wizard of Insurance." 27

Attaway warned that without a black-owned insurance company in Mississippi, white-owned companies would monopolize the black market. He likened the situation to economic enslavement: As fraternals faded away due to their lack of commercial sophistication, white companies swept in and blacks would be forced to carry policies that not only exploited them but also contributed nothing to their communities. Although whole life insurance products cost more than industrial insurance products, they provided an affordable investment vehicle with higher payoffs. Attaway quit his practice, which reportedly earned him $\$ 10,000$ a year, to devote his full attention to Mississippi Life. ${ }^{28}$

Mississippi Life may have been the first black insurer to offer whole life, but it was not the first to want to do so. The very high reserve requirement presented a major impediment for any company interested in starting a legal reserve company. Most states required a minimum $\$ 100,000$ paid-in capital. By contrast, industrial insurance companies required much less, and fraternals could operate without even a formal charter in many states. In November 1910, Mississippi Life's board amended the company's charter, increasing the capital requirement. An exception in Mississippi's insurance laws allowed that only half of the capital, or $\$ 50,000$, had to be paid. However, Mississippi Life could not sell whole life outside of the state until the full amount was paid. The Coxes and board raised an additional

26. On fraternal insurers operating in Mississippi, see State of Mississippi, Insurance Department, "Business Done by Fraternal Organizations: Colored Organizations," in Biennial Report, 1909 to 1911, [page number not printed] (МDAH). Like other insurance companies, Mississippi Life also sold industrial insurance policies of $\$ 50$ to $\$ 200$ for 10 to 25 cents a week.

27. “W. A. Attaway,” Beacon Lights of the Race, edited by Green Polonius Hamilton (Memphis: F. H. Clarke and Brothers, 1911), 516.

28. Ibid., 516-517; and Attaway, "Mutual Benefit Insurance," Report of the Eleventh Annual Convention, 104. 
$\$ 25,000$ in capital at $\$ 200$ a share. Undercapitalization would only be one of the myriad problems faced by the young company. ${ }^{29}$

The Coxes clashed with Mississippi Life's presidents. Attaway was brash and outspoken, perhaps much more than the Coxes could afford to tolerate given the threats of violence against Cox during the Indianola Affair. In addition, Attaway may have seen himself as more forward thinking than the Coxes. He proposed a number of reforms, such as constructing a black mortality table. The company failed to adopt such reforms. However, it was almost impossible for any blackowned fraternal and insurance company to construct such a table at this time. None of the companies collected and pooled together a comprehensive set of mortality statistics. In addition, only about twenty years had passed since blacks entered the field, a relatively short period of time on which to base reliable calculations. Finally, no black actuaries existed. Black insurers were certainly aware of these issues and struggled to address them.

Public hostility between the Coxes and Attaway erupted when he campaigned to relocate the company's headquarters to his hometown of Greenville, a larger town nestled on the Mississippi River. However, the Coxes refused and, as majority stockholders, led the board to shut down Attaway's plans. They then removed him as president of Mississippi Life and helped elect Andrew J. Howard in $1914 .^{30}$

Howard, a math professor, possessed very little executive experience and even less insurance knowledge. He expressed only a nominal commitment to Mississippi Life-financially and professionally. Howard did not fulfill pledges to purchase the requisite amount of stock, and he devoted little time to the day-to-day operations of the company. He continued to maintain his residence in Ebenezer, nearly 70 miles from Indianola. A manager recalled that Howard paid little attention in board meetings. He quickly adjourned meetings, collected his check, and darted out before the last train left for Ebenezer. ${ }^{31}$

29. Stuart, Economic Detour, 284-285; and stock price from Attaway, "Mutual Benefit Insurance," Report of the Eleventh Annual Convention, 105-106.

30. Joseph E. Walker replaced Attaway as president of Delta Penny in 1912. Though the Coxes were the largest shareholders, like some other insurance companies, they sought to build cooperation between shareholders. Thus, they sought board member buy in on decisions, regardless of who owned how many shares. Johnson, From the Driftwood, 37; and Stuart, Economic Detour, 286. On the Coxes social standing with whites in Indianola, see Powdermaker, After Freedom, 111-112; and Washington, "Most Encouraging Convention," Independent, September 20, 1906, 684-686.

31. As in other black companies in the period, executives and board members like Prof. Howard were chosen not for their experience but for their status. Stuart, Economic Detour, 286. 
With no effective leadership, the problems of Mississippi Life mounted: fraud, lack of experienced and qualified agents and employees, and low salaries. Mississippi Life had only a few hundred thousand dollars of insurance-in-force, despite having 27 district offices in the state. By comparison, the fraternals Knights and Daughters of Tabor headquartered in Mound Bayou, Colored Odd Fellows in Holly Springs, and the United Reformers in Vicksburg each had more than \$1 million of insurance-in-force in 1916. Mississippi Life managers and agents absconded with policy payments. Claims languished unpaid on the books. The board had not raised any additional capital in four years, and debts ballooned to $\$ 13,000$. Internal rebellion wracked Mississippi Life's board, which seemed more concerned with returns on investment rather than protecting the company or enacting reforms. ${ }^{32}$

Such poor internal housekeeping reflected poorly on the board's management. Since its inception, Wayne Cox served as Chairman, and Minnie Cox-the only woman executive and board member-served as Secretary-Treasurer. The Mississippi Life board included some of the largest landowners and most prominent civic, professional, and business leaders in Mississippi and nearby Memphis, Tennessee. For example, Dr. W. P. Kyle, who served as the company's Medical Director, was also president of the Mound Bayou Bank in the all-black town of Mound Bayou. Vice President Thomas Henry Hayes Sr. founded what had been, until 2011, the oldest black-owned business in Memphis, T. H. Hayes and Son Funeral Home. He co-founded the Union Protective Life Insurance Company and served as Vice President of the Solvent Savings Bank and Trust in Memphis. ${ }^{33}$

These men looked to Wayne for leadership—not Cox. As long as he tolerated the rampant fraud and mismanagement in the district and local offices, no one else would step forward to address it. Without a list of district or local offices in the state, one can only speculate

32. Fraternal figures in Spectator Company, "Directory of Fraternal Orders," Insurance Yearbook (1916-1917), Insurance Yearbook: Life, Casualty, and Miscellaneous, Volume 45 (1916-1917) (Chicago; New York: The Spectator Company, 1917), 348; and Stuart, An Economic Detour, 286. The Spectator lists Mississippi Life as an active company in Volumes 45 and 46, but all of the financial, board, and company information, except for president and secretary's names, are blank. The yearbooks erroneously list Attaway president, suggesting that the company had not been filing timely reports. Extant copies of reports from the state of Mississippi list Mississippi Life as an active company but often do not include data about its financial standing. See Biennial Reports from 1909-1919 (МDAH).

33. On Kyle, see "Bank in Mound Bayou Closed," New York Age [N.Y.], September 17, 1914, p. 1; Progress of a Race, 256; and "[Mississippi News]," Pittsburgh Courier [Pa.], May 14, 1949, p. 10. On Hayes, see Vance Lauderdale, "Crews Demolish Hayes Funeral Home, Oldest black Business in Memphis,” Memphis: The City Magazine (July 2011), http://www.memphismagazine.com/Blogs/Ask-Vance/July-2011/ Crews-Demolish-Hayes-Funeral-Home-Oldest-black-Business-in-Memphis/; and “T. H. Hayes,” in Beacon Lights, 438-450, here 443-445. 
the reasons such inefficiency and mismanagement were tolerated. It is likely that each board member was granted some autonomy over the offices in and near his hometown. As long as Wayne insured a dependable stream of dividend income, allowed board members the public stature associated with a prestigious black-owned company, and granted them autonomy over affairs in their local spheres of influence, they chose to do nothing to address the internal problems racking Mississippi Life.

In addition to these crippling internal problems, threats from outside caused major concern. White intimidation from individuals, competitors, and state bureaucrats threatened not only the solvency of the company but the safety and lives of its workers. White planters kept Mississippi Life agents from visiting sharecroppers and tenant farmers living on the planters' property. White agents from rival companies and ordinary citizens followed agents after they made collections, attacked them, stole the premiums collected, and tore up the policies. Executives and owners of rival companies pressured the state's Insurance Commissioner, Thomas M. Henry, to exercise whatever regulatory power-and extralegal pressure- - he could call to bear to close Mississippi Life. At one point, Henry told the Mississippi Life board that the company could stay in operation "only as long as it did not get into trouble with the white agents and the white companies." 34 White insurers tested the commissioner's resolve. They charged that Mississippi Life agents tricked and pressured their black clients to switch insurers.

Wayne relied on his connections with influential whites on more than one occasion to convince the commissioner not to pull the company's license. ${ }^{35} \mathrm{He}$ could do little against the extralegal intimidation. However, by 1915, Mississippi Life and its co-founder Wayne Cox were both seriously ailing. His health steadily declined throughout 1915, and he died in a segregated cottage built specifically for his accommodation at Stafford Springs, a sanitarium and resort, in Vossburg, Mississippi, on April 10, 1916. ${ }^{36}$

\section{Minnie Geddings Cox Takes over Mississippi Life, 1916-1920}

Cox immediately took full charge of her and Wayne's personal and business affairs. She managed the financial affairs, paid dividends,

34. Stuart, Economic Detour, 286.

35. Ibid.; McMillen, Dark Journey, 185; "George W. Cox, Manager, Negro Insurance Company, Indianola, Mississippi,” in Progress of a Race, 268; and George W. Cox, "The Insurance Business," Report of the Seventeenth Annual Convention, 93.

36. Stuart, Economic Detour, 288; and “[Obituary]," Crisis Magazine (June 1916), 60. 
and paid off civil court judgments for both the Mississippi Life and the Delta Penny. In 1917, the court awarded her Wayne's small amounts of profitable stocks in other companies, including several black-owned firms; his 85 percent controlling interest in the Delta Penny; and his 100 shares of Mississippi Life stock. ${ }^{37}$ Cox operated in the shadows during her husband's lifetime, but now she stepped into the limelight.

It is important to consider why, as Secretary-Treasurer of the company since its founding, Cox ignored clear signs of mismanagement and fraud in its ranks for nearly a decade. While Wayne respected her partnership in all areas of their personal business lives-managing their scores of rental properties, lending money, and entertaining business colleagues-he could ill afford her assertiveness among his colleagues. He had to appear in charge. Wayne Cox was a well-respected businessman and politician, and Cox did not want to undermine his public image. As long as the bank remained on solid footing and the couple continued to enjoy personal success, they were content to allow the executive officers of Mississippi Life to operate unfettered.

If Cox chose to step into her husband's unexpired term, as some wives of powerful executives did, few would have expected her to serve in more than a titular role. For example, Jessie Gillespie Herndon became vice president of Atlanta Life after her husband Alonzo Herndon's death, but she deferred the day-to-day management of the company to her stepson and board. ${ }^{38}$ However, Cox orchestrated a bold plan to revive Mississippi Life. Cox held the most powerful office in the company: As secretary-treasurer she exercised direct control over both the company's finances and administrative functions. Cox became a force with which to be reckoned. She drew on the expertise of the general manager, Merah Stuart, and local Indianola physician Dr. Joseph Walker, Wayne's initial choice for president in 1908.

Cox removed Prof. Howard from office, loaned Walker the money he needed to purchase the requisite number of shares, and advanced Walker's election to president of Mississippi Life in $1917 .{ }^{39}$ Cox, along with Stuart and Walker, transformed Mississippi Life in less than a year. They sold the outstanding $\$ 40,000$ in shares so the company could sell life insurance outside the state. They cured the $\$ 13,000$

37. "Petition to Be Allowed to Finish Furnish Contractors, Manage Crops, Etc.," Filed May 17, 1916, and “Final Account," Filed May 18, 1917, both in wwc Probate Records.

38. Merritt, The Herndons: An Atlanta Family (Athens, Ga.: University of Georgia Press, 2002), 209.

39. Cox was also elected vice president of the Delta Penny. "Mississippi Beneficial Life Insurance Company a Great Insurance Company,” Broad Axe [Chicago], January 24, 1920, 2; "Walker Family," African American Business Leaders, 655-656; and Johnson, From the Driftwood, 37-38. 
encumbrance, modernized office procedures, increased office staff, hired experienced agents, and streamlined the district office system. They rooted out corruption and inefficiencies that had bled the company for nearly a decade. Premium income increased to over $\$ 194,000$. By the end of the decade, Mississippi Life expanded into Alabama, Arkansas, and Tennessee. In 1920, premium income surpassed the half million mark (or more than \$5.9 million in 2015 dollars). The entire sales force topped 250 men and women. ${ }^{40}$

The reforms extended to the branch offices. Walker instituted quarterly district meetings to train and inspire agents. The district meetings were part pep rally, sales training, and industry education. The two- to three-day meetings featured luncheons, dinner banquets, and awards ceremonies with keynote speeches by Mississippi Life stockholders, officers, or board members. Leading sales agents in the company led sales training workshops in which agents role-played common sales scenarios, such as how to meet objections or promote the company's products. The best solutions won prizes. Training sessions featured subjects such as "Efficiency," "Salesmanship," “An Agent's Duty,” and "How to Increase a Debit." Nurses and physicians provided information about health-related topics, such as the spread and prevention of infectious diseases. The district meetings assured that agents received vital training and helped them stay committed to the company. ${ }^{41}$

The biggest change occurred in 1919 when Cox changed the company's name, removing “Beneficial” to create Mississippi Life Insurance Company. The name change symbolized the company's disassociation with fraternal insurance. Many insurance companies formed at the end of the nineteenth century and beginning of the twentieth included words like Beneficial, Benefit, and Benevolent in their names to link them with fraternal insurance in the minds of potential customers. By the late 1910s, many saw the association with fraternalism as a detriment. With the elision of one word, Mississippi Life asserted an identity that resonated in the context of a modern insurance industry that had become increasingly more complex, professional, and corporate. It also affirmed that Cox was now in charge.

The changes in the company led to positive growth but not without making some complicated decisions about its customers. Though the industry emphasized the ways insurance represented provision and

40. Tucker, “Black Pride,” 437; Stuart, Economic Detour, 171-172, 288; Lee, Beale Street, 184-185; Bryson Jr., "Negro Life Insurance Companies,” 26-27; premium figures from Spectator Company, Insurance Yearbook (1921-1922), 184; and premium and workforce figures from “A Prosperous Institution," Chicago Defender [Ill.], April 6, 1918, p. 3.

41. See detailed description of one such district meeting in "Mississippi Life Holds District Agents Quarterly Meeting,” Dallas Express [Tex.], December 1, 1923, pp. 1, 8. 
protection in the event of death, insurers made money by not paying claims-even legitimate ones. Mississippi Life dodged paying legitimate claims. For example, Pleze Oates, a thirty-year-old farmer living in Mound Bayou, bought a whole life insurance policy in November 1915 and faithfully paid his \$12.94 quarterly premiums. After he died in February 1919, Oates' father Washington tried to collect the $\$ 1,000$ benefit. Mississippi Life refused to pay the full amount, claiming that Oates had an unpaid $\$ 70$ loan against his policy and that his policy had lapsed a month before his death due to non-payment. The company offered to pay $\$ 150$, which represented the "paid-up endowment value." 42 Oates' father sued. He produced evidence that Oates had applied for and paid off a small loan June 1918. Oates applied for a new loan for $\$ 70$ but died before signing the promissory note or receiving the funds. Washington produced the unsigned policy loan agreement and Oates' cancelled checks showing premiums paid in full through March 1919.43

The company certainly had not expected Oates to keep such accurate records. Indeed, it relied on policyholders' poor recordkeeping and lack of resolve. The decision to offer Oates's beneficiaries a pittance, despite the fact that Oates had faithfully paid his premiums for nearly four years, reflected a calculated decision to force the client to prove the company owed the benefit. Whole life benefits paid three to ten times more than typical industrial or fraternal policies. Unlike fraternal insurers, who often made a public display of paying premiums as a way to bolster the fraternal's reputation and increase members' loyalty, Mississippi Life maintained layers of bureaucracy between themselves and the policyholder. It often made better business sense to question rather than pay claims. The court ruled against Mississippi Life and ordered it to pay the full $\$ 1,000$ plus six percent interest and court costs. ${ }^{44}$

42. The terms of the policy allowed a smaller payout based on a rate that paid nothing if death occurred in the first two years, \$150 in the third year, and \$50 increases every year thereafter up to $\$ 1,000$. P. W. Howard, “[Mississippi Life] Answer, Filed October 10, 1919," Mississippi Life $v$ Oatis. Note that Oates' name and those of his beneficiaries are misspelled in the court documents; see correct names in "Washington Oatis (Colored), Direct Examination," 10 and "U.S. Census, 1920," index and images, Reese Oatis in entry for Washington Oatis, 1920, FamilySearch, https://familysearch.org/pal:/MM9.1.1/M43W-2NL.

43. "Summary" (pp. 3-4); "Washington Oatis (Colored), Direct Examination" (pp. 9-32), and "Note, Policy No. 1686, June 6, 1918” (pp. 24-25), in Mississippi Life $v$ Oatis.

44. Mississippi Life prevailed in an appeal of a case in which poor recordkeeping on the part of a Mississippi Life agent bolstered the defendant's claim. A Sunflower Court ruled that General Bismark Stephens' widow should receive some money, but she was not able to produce adequate documentation of their payments to satisfy the Supreme Court; see Mississippi Life v Stephens. Oates court decision in “Decree, June 18, 1920," in Mississippi Life v Oatis. 
Despite losing some suits, Mississippi Life was a veritable success. Unfortunately, its newfound success made it even more vulnerable to white hostility. It again became the target of marked resentment from white companies who refused to stomach serious competition. In addition, the mass migration of blacks out of the South for betterpaying jobs and opportunities in the North and Midwest occurred at a time when wartime demand for cotton and foodstuffs augured unprecedented demand and profits for planters. More than 100,000 blacks left Mississippi between 1915 and 1920. The mass movement of blacks fueled resentment and heightened anxieties. ${ }^{45}$

White men in Indianola, their ranks swelled by poor white migrant workers, subjected the company to a sinister but long-standing form of harassment: They sexually threatened and may even have attacked the company's female office workers and sales agents. ${ }^{46}$ The headquarters maintained an estimated workforce of fewer than 20 people, but the presence of the black women who worked there did not go unnoticed. Working at Mississippi Life enhanced black women's options and financial autonomy. Census records highlight that at least one of the women working as a sales agent reported that she did not know how to read or write. ${ }^{47}$ It is not known if she worked strictly on commission or received some wage, but working as an agent was infinitely better than the only other jobs available to black women in Indianola: domestic, washer woman, and laborer.

By 1919, the widow Cox could no longer rely on the intercession of the influential whites she and her husband had cultivated for nearly 40 years. Perhaps these sympathetic whites had passed away, succumbed to the intimidation of their peers, or performed their own social calculus and believed continued association with Cox was more a detriment than a benefit. However, it is more likely that Cox performed her own calculus. Indeed, communities around the country were erupting in riots and indiscriminate violence, fueled in part by resistance to black soldiers returning from service in World War I and to black migration. In the Mississippi Delta region, one of the most violent riots in U.S. history occurred in 1919 in Elaine,

45. Cotton prices increased from 11 to 20 cents per hundred pounds in 1916, to 28 cents in 1917, and reached a record high of 43 cents in June 1919; see Woodruff, American Congo, 42. Black emigration figure from Woodruff, American Congo, 40.

46. The record is sparse with regard to documenting specific incidents and attacks; see Johnson, From the Driftwood, 39. On poor white workers migrations across the Mississippi Delta, see Woodruff, American Congo, 42.

47. Number of employees in the home office estimated from census data. Sales agent Lucille Washington is listed in the 1920 census as not knowing how to read or write; see note 48 . 
Arkansas, when mobs there brutally repressed an agricultural labor reform movement. ${ }^{48}$

Cox refused to tolerate the threat of rape and the explicit comments and gestures directed against her female workforce-and, indirectly, against their husbands, brothers, fathers, and male co-workers. She certainly realized that lynchings and mob violence were the only one-sided "justice" blacks resisting sexual terror would ever receive. She also realized many whites in the small town and largely rural county would never countenance the sight of women like sales agent Lucille Washington; clerks Willie May Brown, Marthia Porter, Paeolo Wallace, Velma Capshaw; and stenographer Minnie Ashwood. Many whites felt these women should be working in their kitchens or fields-not in the headquarters of one of the largest black-owned life insurers in the country. They expressed their outrage through violence and intimidation. Blacks responded through organized protest, armed resistance, and flight, which comprised grassroots and associational resistance in the period. Cox decided to move the headquarters of the company to Memphis. ${ }^{49}$

In 1919, Cox approached the board with the idea of moving the company out of the state. New Orleans was offered as a possible new location, but Cox and a number of other board members settled on Memphis because of its geographical, economic, and strategic advantages. It was about 135 miles north of Indianola, and both the city's black population and "Black Wall Street," anchored by Beale Street, were thriving. By 1920, only a handful of black fraternals offered insurance in Tennessee, though Mississippi Life, North Carolina Mutual, Atlanta Life, and Standard Insurance of Atlanta, the other leading black-owned legal reserve insurers, operated small district offices in the city. ${ }^{50}$

The board tried to keep the company's move a secret, but word of its plans leaked. The backlash was immediate. Dr. Joseph E. Walker recalled local reactions: "[M]any of the local stockholders sold their stock; policyholders threatened to cancel their policies; school teachers met and sent in petitions; [and] ministers who had used their pulpits

48. On causes of World War I-era violence, including seething racial tensions, competition for jobs, and the Red Summer, see McWhirter, Red Summer, 10-11, 19, 22, and passim and Tuttle, Race Riot, 14-21. On Elaine Massacre, see Whitaker, On the Laps of Gods, 83-87, 134-135, and 122-126; Woodruff, American Congo, 74-109; and Stockley, Blood in Their Eyes.

49. Women's names from 1920 U.S. Census, Sunflower County, Indianola, Mississippi, Enumeration District 119, Sheets 3A, 5A, 5B, 13B, and 14B, National Archives Microfilm Publication Series T625, Roll 894, pp. 73-75, 83, and 84, http:// www.heritagequest.com.

50. For fraternals operating in Tennessee, see tables "Fraternal Insurance Orders" and "Fraternal Orders of Other States," in State of Tennessee Department of Insurance, Annual Report of Insurance Commissioner, 218-219. 
to boost the great enterprise now spoke out against it."51 Those white merchants who profited from the business of the company's employees and customers also complained bitterly about Mississippi Life's planned departure.

The reaction of state regulators was more perplexing. As long as the company obeyed the insurance laws and displayed the proper obeisance, regulators avoided efforts to close the company. Commissioner Henry was unwilling to part with the $\$ 100,000$ in assets and securities deposited with the state. The business could move, but its money had to remain. To avoid a protracted battle, Cox left the company seal in the hands of fellow board member and close friend W. W. Phillips in Kosciusko, Mississippi, and on August 19, 1920, left for Memphis. Mississippi Life opened its new headquarters at 234 Hernando Street in Memphis. ${ }^{52}$

\section{The Beginning of the End of Mississippi Life, 1920-1923}

The "Delta blues" followed Cox to Memphis. A Mississippi Insurance Department examiner trekked to Memphis and claimed the company was impaired $\$ 20,000$ through mismanagement in the Ordinary Department. Cox disagreed with the examiner but wrote a personal check to cure the impairment. In February 1921 at the stockholders meeting held in Clarksdale, Mississippi, Cox and the board discharged the supervisor of the Ordinary Department. The time in Clarksdale proved profitable for Cox: She convinced several smaller stockholders to sell her their shares, strengthening her majority position in the company. By 1923, she owned 85 percent of the shares in Mississippi Life, which were worth the equivalent of \$1.2 million in 2015 dollars. ${ }^{53}$

Memphis also presented its own kind of "blues." White resentment had been a problem in Indianola, and now, as one of the largest and newest black-owned business in Memphis, black resentment became a serious problem. Mississippi Life's home office at the corner of Hernando Street and Beale Street physically represented the company's imperfect entry into Memphis's black community.

Beale Street in Mississippi quickly emerged as one of the nation's successful Black Wall Streets, enclaves of thriving black-owned

51. Quote and merchants' reactions from Johnson, From the Driftwood, 42-43.

52. Stuart, Economic Detour, 288-289; and date of departure in Johnson, From the Driftwood, 43.

53. Stuart, Economic Detour, 289; and amount of shares from "The Standard Life Shortage and Mississippi Injunction Stir Nation," Dallas Express [Tex.], March 8, 1924, p. 1. 
businesses and communities. ${ }^{54}$ By the end of World War I, Beale Street boasted two banks with combined deposits of $\$ 1.5$ million (or \$17.9 million in 2015 dollars), a coffin manufacturing company with a factory in Memphis and assembly plants in five other cities, a grocery store chain with 15 stores, a hotel, nightclubs, restaurants, and other service businesses. ${ }^{55}$ People of all classes mingled on and around Beale Street. Mississippi Life became the largest business near Beale Street when it opened its new office in the late summer of 1920. However, its arrival revealed some of the deep fissures of intraracial politics and class in the city.

The company's icy reception was part formal politics and part cultural politics. Robert R. Church Jr., scion of one of the wealthiest blacks in the country, and arguably the most influential black in Memphis and the Mid-South, controlled Memphis politics. Church, a Republican, founded the Lincoln League in 1916 and helped form the state's first National Association for the Advancement of Colored People (NAACP) branch after a gruesome lynching in 1917. Because Republicans had almost no chance of election in the solidly Democratic South, Church backed Democrats at the local level whom he believed would help blacks. As a testament to Church's political influence, 19 of the 20 candidates for local offices in the fall of 1918, including mayor, had been promoted and supported by Church and his Lincoln League. However, once elected, many politicians reneged on campaign promises to black constituents. ${ }^{56}$

Mississippi Life ventured into this dynamic political, economic, and social climate-but not completely unaware. George W. Lee served as district manager of Mississippi Life's Memphis office. Lee's ambition and business acumen established him as one of Church's most important machine lieutenants. However, Joseph Walker strongly resisted entreaties to join the Church faction. It is not known if Cox supported Church's powerful political machine. Whether she did or not, she gained the ire of Church's enemies who assumed she allied with him and the enmity of Church supporters who assumed she had not. ${ }^{57}$

54. For a broad survey of African American business enclaves, see Butler and Wilson, "Entrepreneurial Enclaves"; and Quincy T. Mills, "Black Wall Street," in Encyclopedia of African American Business History, 81-82.

55. Tucker, Lieutenant Lee, 43-44.

56. Gritter, River of Hope, 52-56, 60.

57. Cox was already acquainted with Church and his father. The Coxes owned stock in and Wayne had served on the board of the Solvent Savings Bank and Trust Company, the bank Church Sr. founded in 1906. See Walker's anti-Church and anti-Crump political orientation in Ibid., 5, 10, 93, 117-122, and 128-128; Holtzclaw, Black Magnolias, 164; and Johnson, From the Driftwood, 50. 
The other part of the hostility to Mississippi Life stemmed from cultural politics. Memphis's black civic-business elite was not necessarily a tight-knit community, but the looming presence of Mississippi Life could not be ignored. Cox did not seek its good graces as part of her tactical calculation in moving to Memphis. A contemporary observed that "no invitations to open doors were extended for publicity meetings, no public banquets were held, no private dinners were served, nor was there publicised $[\mathrm{sic}]$ anywhere an 'Open House."”58 It is also not likely that she curried favor from Memphis's circle of elite black women beyond maintaining ties with those friends and acquaintances she already had. The unintentional snub moved Memphis's black middle class to shun Mississippi Life in social and economic circles. ${ }^{59}$

By 1923, Cox wished to sell her company. Her decision may have been motivated by the company's success or her frustration with other well-to-do blacks. Mississippi Life's president Dr. Joseph Walker probably expressed some reservations about the sale. A cautious and conservative executive, he certainly insisted on a full vetting of any potential buyer. Cox relied on Walker in the past, but now he represented an impediment. She needed him out. She nominated her son-in-law Dr. Wayne Howard of Bessemer, Alabama, for president, and demanded Walker's resignation.

At first, Walker refused to step down. He trusted his long record of accomplishments to speak well of his benefit to the company. It is not clear how much money he still owed Cox on her 1916 loan that allowed him to buy the required number of shares to sit as president of the company. The move to Memphis exhausted his personal savings. If he still owed Cox money, she probably exercised that leverage over him. Unable to prevail over Cox, Walker formally resigned on February 22, 1923. Dr. Howard, unlike his brother, former president Prof. Andrew Howard, did not assume even token responsibility at Mississippi Life. He remained in Alabama rather than move to Memphis. Cox, in complete control of every aspect of Mississippi Life, could direct its sale with no interference. ${ }^{60}$

58. Johnson, From the Driftwood, 43.

59. Walker's biographer attributed the icy reception of the company to Memphis business leaders who considered Walker "a 'little fry' coming out of the cotton fields of Mississippi” (Ibid., 47). On Memphians' reactions to Mississippi Life, see "Joseph Edison Walker," in Mississippi Black History Makers, 172, and Johnson, From the Driftwood, 47. Revenue figures from Stuart, Economic Detour, 224.

60. Walker's biographer's version of events is that Heman Perry traveled to Bessemer, Alabama, to convince Cox's son-in-law to sell the company. Perry maligned Walker's reputation, which led Dr. Howard to oust Walker during the stockholder meeting. This version of events confers far too much power to Walker and Howard. It is highly unlikely that Ethyl Cox Howard would allow her husband 
Desire and means were only two components of a successful sale. She needed a buyer-and not just any buyer. Without question, the buyer had to be another black insurer. Appeals to race pride had been a mainstay in the black separate economy, particularly among insurance companies, large and small. The field of potential buyers was small, but the right one seemed to appear in Heman Perry, founder of Standard Life Insurance Company of Atlanta. It is not known when Cox and Perry first met to discuss a sale. When Perry called on her, by coincidence or invitation, his reputation as the wealthiest black financier preceded him.

Perry organized Standard Life of Atlanta in 1908. In 1913, Perry brokered a financial deal with Atlanta Life to protect it from white competitors. That same year, Standard Life became the first black insurance company to offer whole life insurance products exclusively. The insurance company formed part of a stable of Perry companies, which included Citizens Trust Bank, an engineering and construction firm, and a pharmacy. In 1924, Perry gained national prominence when Forbes magazine featured him as the richest, most successful Negro businessman in the world. Among the black community, he was known as "The Daddy of Negro High Financing."61

In Perry, Cox met a formidable ally-and foe. By the early 1920s, unknown to all but a handful of insiders, Standard Life teetered on the verge of financial collapse. Perry desperately needed the assets of Mississippi Life to save his empire. Desperation led him to seek acquisition of Cox's company by unscrupulous means. Early in 1923, Perry dispatched his actuary James R. Cothran, an associate actuary

to take any major action against her mother. Ethyl was fiercely loyal to (or easily intimidated by) her mother. For example, she signed over her inherited assets and interest in her father's companies to her mother (see wwc Probate Records). In addition, Howard could not orchestrate any action among stockholders except under her direction and with her permission and support. Cox certainly orchestrated Walker's removal, not Howard. Howard made an excellent choice of replacement because he was more malleable than Walker. Walker's biographer diminishes Cox's role in the company, writing for example that Minnie Cox, "with tears in her eyes, begged [Walker] to assume the presidency" because the company "was slowly moving towards the brink of disaster and needed the strong arm of competent youth to withstay it and bring it back to a condition of normalcy." Version of affairs and quotes in Johnson, From the Driftwood, 51; "Howard, Wayne Cox," Who's Who, 144; and Stuart, Economic Detour, 289-290 and 306-307.

61. On race pride in the insurance industry, see Weare, Black Business, 74. On Perry, see Hardman and Robinson, "Perry, Heman Edward"; Pace, "Organizing the First Old Line Insurance Legal Reserve Insurance Company among Negroes," Report of the Fourteenth Annual Convention, 154; Walrond, "Largest Negro Commercial Enterprise"; Henderson, "Heman E. Perry," 217 and 221; and "Daddy" sobriquet from "Standard Life and Southern Insurance Companies Merge," Broad Axe [Chicago], January 24, 1925, p. 2. 
with the John A. Copeland firm of Atlanta, to the Mississippi Life offices on Hernando Street. Cothran, concealing his association with Perry and perhaps implying he was acting in an official state capacity, asked to look over the company's books. The office complied. He suggested that Mississippi Life engage his services and allow him to invest and grow its cash surplus. If the Mississippi commissioner balked, Cothran bragged that he would bring the power of the national professional association of actuaries to bear against Henry. ${ }^{62}$

Initially at least, Cox was unaware of Perry and Cothran's ulterior motives. Mississippi Life did hire Cothran, a move it could not have made without Cox's knowledge or approval. Cox knew the commissioner's capriciousness regarding Mississippi Life, but she felt Cothran could provide leverage she needed against Commissioner Henry. Perhaps she felt the recent controversy over Henry's handling of state funds and his removal from office for a short time in 1922 also provided leverage she needed to resist his demands. ${ }^{63}$ To be sure, Cox's motivations may have been completely self-interested: She would agree to anything Perry wanted to grease the wheels of the sale to Standard Life.

Armed with the knowledge that Mississippi Life was indeed on solid financial footing and the "cash cow" Perry needed to ease his financial troubles, he then tried to woo away Cox's key employees. For example, Perry invited General Manager Merah Stuart to Atlanta and feted him in grand style: tours of the city and Perry's businesses, expensive dinners, and meetings with top executives at Standard Life. In late September 1923, Perry offered Stuart a $\$ 6,000$ a year position in Standard Life's soon-to-be-launched industrial life insurance department. Perry gave Stuart little time to mull his options: The position started on November $1 .{ }^{64}$

Stuart resigned from Mississippi Life and left Memphis for Atlanta. Once at Standard, Stuart quickly surmised that neither Perry nor anyone else was interested in creating a new industrial life department.

62. Cothran's association with Standard Life deduced from his name on Standard Life's letterhead; see images of Heman Perry to Merah S. Stuart, September 25, 1923, reprinted in Stuart, Economic Detour, 292. On Cothran's visit to Memphis office, see Stuart, Economic Detour, 290-291.

63. Henry was accused of defaulting on nearly $\$ 50,000$ in funds paid by insurance companies to his office. The governor briefly appointed Excell O. Coody to replace Henry. See "Insurance Commissioner T. M. Henry Removed," Hinds [Miss.] Gazette, July 14, 1922 in Subject File: Henry, T. M. (MDAH), and the more sympathetic “Suspends Commissioner Henry," The Standard, a Weekly Insurance Newspaper, July 15, 1922, 91.

64. Johnson, From the Driftwood, 58-59; and Stuart, Economic Detour, 291-293. Perry also invited another unnamed employee. Stuart's version of events does not include any mention of a visit to Atlanta. 
When Stuart protested, Perry bragged that Commissioner Henry planned to pull Mississippi Life's license because it had hired an actuary, Standard Life's own Cothran, without Henry's permission. Soon after their confrontation, Stuart traveled to Jackson, Mississippi, to meet with the commissioner to ascertain if the threat against Mississippi Life's license was accurate. ${ }^{65}$

Henry told Stuart that because of repeated "confusion and disobedience to [his] orders," he did indeed plan to revoke Mississippi's Life's license. ${ }^{66}$ Its last day of business, Henry proclaimed, would be December 31, 1923. Stuart immediately left for Washington, D.C. to confer with Mississippi Life's General Counsel Perry W. Howard, the brother of the current and former Mississippi Life presidents. Atty. Howard was Special Assistant to the U.S. Attorney General, the highestranking black federal appointee in the country. Howard assured Stuart that he would handle Henry "in fifteen minutes." 67 Howard called his brother in Bessemer and later spoke with Cox. Cox must have made it clear to her attorney that she intended to sell. He then advised Cox, his brother Howard, and Cox's daughter Ethyl Cox Howard that they should sell their combined shares to Perry under the following three conditions: Perry had to pay them in cash; the minimum acceptable offer was $\$ 125$ per share; and Perry had to pay attorney's fees and expenses. Cox and her attorney agreed that Perry must understand that, should he choose to sell Mississippi Life later, he could only sell to another black insurance company. ${ }^{68}$

A few days after Atty. Howard's consultation with Cox, Perry met with the attorney to hammer out the deal at the black-owned Whitelaw Hotel in Washington, D.C. Perry agreed to all of the terms and even sweetened the deal. He offered $\$ 150$ a share and offered to reimburse Cox the $\$ 20,000$ she paid in 1921 to satisfy the impairment alleged by the state examiner. Howard stressed again that Cox's \$128,000

65. Stuart, Economic Detour, 291-229; and Perry to Stuart, September 25, 1923. 66. In their meeting, Stuart reminded Henry that he had only said the company could not use a specific actuary: Andrew Sigtenhorst. Sigtenhorst was an actuary based in Waco, Texas, who worked with some of the largest black fraternal and private insurance companies in the country. In not allowing Mississippi Life access to his expertise, Henry probably hoped to hobble the insurance company. Stuart, Economic Detour, 293.

67. Howard lived in Washington, D. C. because of his federal appointment. Though he resided in Washington, D.C., Howard was also still powerfully placed within the Mississippi Republican Party; see McMillen, "Perry W. Howard."

68. After the sale, a newspaper reported that "It was understood by Mr. Perry when he bought stock in the Mississippi Life Insurance Company that his stock would not be sold to any white concern and Perry agreed not to do so"; see "Injunction Prevents the Sale of the Mississippi Life Company," Dallas Express [Tex.], March 8, 1924, p. 2. Other details of sale from Stuart, Economic Detour, 293-294. 
(or \$1.8 million in 2015 dollars) and the others' proceeds had to be paid in cash. ${ }^{69}$ Perry assured him cash would not be a problem.

In early November, Cox, Dr. Howard and Ethyl, Atty. Howard, and Perry met in the small town of Bessemer, away from the prying eyes of Memphis. Cox was not feeling well, and it did not help her condition that Perry showed up without the cash in hand. He claimed he had simply neglected to wire the funds. Instead, he offered personal checks of $\$ 20,000$ to each member of the family and $\$ 4,500$ for the attorney's fees and three promissory notes for the remaining balance. Atty. Howard insisted Cox wait until the personal checks cleared before moving forward with the promissory notes. This time, she heeded his sage advice. As none of the checks cleared Citizens Trust, any doubts about Perry's financial condition were confirmed. ${ }^{70}$

Atty. Howard, together with Lt. Lee and Stuart (who had returned to the ranks of Mississippi Life), mobilized to protect the company. The attorney threatened legal action against the state of Mississippi, and Memphis District Office Manager Lt. George W. Lee and Stuart threatened to dissolve the company's debits. A desperate Perry suggested that Cox deposit $\$ 80,000$ of Mississippi Life's cash surplus in Citizens Trust, which was also in dire straits. He could then use those funds to pay Cox, Dr. and Mrs. Howard, and Atty. Howard most of the money he owed them. In essence, Perry suggested using Mississippi Life's own money, much of it Cox's, to pay for her company. ${ }^{71}$

Cox deposited \$20,000 of Mississippi Life’s surplus in Citizens Trust, probably against her attorney's counsel. Four of Perry's personal checks subsequently cleared. The motivations acting on Cox's decision to spend her own money to save the sale came from various quarters.

69. Merah Stuart reports that Cox owned 720 shares; a newspaper account reports that she owned 850 ("The Standard Life Shortage"). I have based these figures on Stuart's numbers.

70. The notes were to be paid in bi-weekly installments between November 15 and December 31, 1923. Citizens Trust was the bank organized and owned by Perry. Stuart, Economic Detour, 294-296; and Perry W. Howard to Merah Stuart, November 16, 1923, reprinted in Ibid., 297.

71. Before and after the sale, Perry did try to resolve his debts with Southeastern Trust. He declined a loan arranged by Robert R. Moton, president of Tuskegee Institute, from Julius Rosenwald, John D. Rockefeller, and Trevor Arnett. The white businessmen were willing to save Service Company to preserve "faith in black business," but they would do so only on the condition that new management was secured. Perry refused to step down. Perry then courted National Benefit Life Insurance of Washington, D.C., but, by 1925, National Benefit tried to buy Standard Life to keep it from falling into the hands of a white company. Ironically, the attempted purchase further undermined the National Benefit and hastened its failure. See Mitchell, Collapse, 34-42; Henderson, "Heman E. Perry," 235; Dailey Jr., "Business Life," 679; Lee, Beale Street, 188; "Standard Life is Gobbled Up,” Cleveland Gazette, January 24, 1925, 1; Stuart, Economic Detour, 299; and "Philanthropists' \$500,500 Couldn’t Save Standard Life,” Afro-American, May 7, 1932. 
Her actions undercut Howard, Lee, and Stuart's efforts to save the company, but Cox must have believed that combining Mississippi Life and Standard Life would resolve Perry's financial problems while achieving her ultimate goal of creating the largest black-owned life insurance company in the country. Few were aware of the seriousness of Perry's financial troubles, and Cox may have believed that he needed an infusion of cash to help with a temporary financial difficulty. Perry was finally able to borrow the remaining funds to complete the sale from Southeastern Trust Company. Southeastern Trust already possessed virtual control of Citizens Trust and Perry's holding company, Service Company, which meant that the white-owned company effectively controlled not only Standard Life, but also Perry's numerous other firms. ${ }^{72}$

On December 10, 1923, Perry and the top officers of Standard Life, Commissioner Henry, and a Southeastern Trust officer arrived at the Mississippi Life offices with a check for \$86,000, significantly less than the original terms. ${ }^{73}$ Perry refused to give Cox the check until she and Dr. Howard transferred their stock to Service Company, elected Perry president, and elected the two Standard Life officers he brought with him secretary-treasurer and vice president. ${ }^{74}$ Cox realized that her hands had been on the lever even as her carefully laid plans barreled out of control.

Cox assessed her options. Commissioner Henry's threat to revoke the company's license was more than an idle one. Atty. Howard could challenge the action in court, but it was unclear how long it would take to get the company's license reinstated or how much it would cost to do battle with the state of Mississippi. If she kept the company, she would operate in a hostile environment with the added burden of an uninterested and inexperienced president, her own son-in-law, at the helm. Walker's removal and Stuart's quick defection also gave her pause about who she could really trust. She was 54 years old, and she had spent much of her life fighting to build and then preserve the monument of protest she and her husband created. She took the money and signed over the company to Perry. The ink was hardly dry before the new officers wrote checks transferring all of Mississippi Life's liquid assets to Perry. Perry endorsed those checks to the white

72. Stuart, Economic Detour, 299; and Lee, Beale Street, 188.

73. The $\$ 86,000$ figure from Stuart, Economic Detour, 299. However, some newspapers reported that Perry paid $\$ 120,000$ for the company; see "Doings of the Race," Cleveland Gazette [Oh.], December 22, 1923, p. 3.

74. "Atlanta Combine Now Controls Miss. Life," Chicago Defender [Ill.], December 22, 1923, p. 1; Stuart, An Economic Detour, 299; Lee, Beale Street, 188; and "Big Insurance Deal among Colored People Perfected," Negro Star [Wichita, Kan.], April 25, 1924, p. 1. 
Southeastern Trust agent present at the meeting, a partial payment against his more than half a million in debts.

In a little over a year, Standard Life would cease to exist as well. On February 16, 1925, the remaining stockholders and the new officers met in Holly Springs, Mississippi. Secretary James RobinsonPerry did not attend-advised the stockholders that Standard Life was transferring its majority stock to Southern Life, a white-owned insurance company in Nashville connected to Southeastern Trust. The acquisition of Standard Life, flush with Mississippi Life accounts, immediately ranked Southern Life among the ten largest insurance companies in the South. ${ }^{75}$ With the stroke of a pen, Mississippi Life, the monument of protest Cox and her husband built in defiance of efforts to circumscribe black initiative, was no more.

From the beginning, Southern Life struggled with its new acquisition. ${ }^{76}$ Black policyholders refused to pay their premiums to white agents. Many customers allowed their policies to lapse, transferred their business to other black-owned firms, or cashed out their policies. Mississippi Life staff and agents walked out of the Hernando office in protest. Twenty-seven managers representing 600 agents in five states traveled to the Memphis offices to join protests against the takeover. Will Harris, the owner of Southeastern Trust and new secretary-treasurer of Southern Life, publicly grumbled, "I wonder why Perry would try to sell his people to members of other races, and can't deliver [them]."77 By the end of 1925, Southern Life looked to dump its Mississippi Life business. In an ironic twist, Joseph Walker,

75. Stuart, Economic Detour, 300, 302, and 309; "Race Business Men Redeem the Mississippi Life Insurance Company," Broad Axe [Chicago], September 18, 1926, 2; and ranking in "Perry Fails to Get Rosenwald Loan," Topeka Plaindealer [Kan.], February 6, 1925.

76. Perry tried to dodge criticism for the sale by making several false claims. First, he claimed financial mismanagement, personnel problems, lax medical examinations, and a negligible whole life insurance portfolio devalued the stock price to under $\$ 100$. These factors in conjunction with "strong opposition within Standard Life" led him to determine that a merger between the two companies was no longer desired. He then claimed that no other black company could afford to purchase Mississippi Life at the asking price of $\$ 200$ a share. He was willing to sell the company to North Carolina Mutual Insurance Company (NCMIC) for $\$ 40,000$ less than the asking price, but the Mississippi Insurance Commissioner refused to accept these terms. Perry claims he offered to put up $\$ 20,000$ of the shortfall if NCMIC would contribute an additional \$20,000 and give up the Mississippi Life's ordinary (i.e., whole life insurance) debits. NCMIC and another unnamed colored company refused those terms, and Perry had no choice, for the "protection of policyholders and shareholders of Mississippi Life," but to sell to Southern Life, which offered \$310 a share. See "Perry Explains Deal. Standard President Relates Details in Mississippi Deal; Race Concerns Refused to Buy," Houston Informer [Tex.], March 29, 1924, p. 1.

77. "Injunction Prevents the Sale." 
the ousted former president, purchased Mississippi Life's accounts and moved Universal Life, the company he formed less than a year after his dismissal, into Mississippi Life's former headquarters on Hernando Street. ${ }^{78}$

The realities of the world of commerce had steeled Cox. She thought in business terms but also in terms of legacy to the race. She wanted profits for herself and other Mississippi Life shareholders but she also wanted to keep the company within the race. Others shared her vision for and commitment to create a powerful race company. One newspaper stressed that the merger "would give the Race $[\mathrm{sic}]$ the largest insurance company that has ever been operated by Negroes and enable them to do a work that would be very far reaching in many phases of business."79 She chose to sell Mississippi Life to another powerful black insurance companybut not the most obvious choice, North Carolina Mutual (NCMIC), already the largest insurance company in the race. Her nephew defected to NCMIC, and she resented him and NCMIC for it. ${ }^{80} \mathrm{~A}$ mixture of vision, resentment, and ambition drove Cox to create the largest black-owned life insurance company in the country as the ultimate monument of protest for a life spent fighting Jim Crow through enterprise.

Minnie Cox and her experiences building Mississippi Life reveal the novel experience of an enterprising black businesswoman, but her story shifts our attention away from the typical ways of describing early twentieth century black women. No extant evidence has been uncovered of Cox's involvement in the clubwomen movement

78. “Joseph Edison Walker," in Mississippi Black History Makers, 173; "Black Insurance Companies 1977: An \$11 Billion Industry,” Black Enterprise (June 1978), 145-146, 148, and 150, 146 and 148; Lee, Beale Street, 189-190; Stuart, Economic Detour, 305-306; Woodson, "Insurance Business," 225-226; and McMillen, Dark Journey, 185. On details of Universal Life's founding and sale of debits, see Johnson, From the Driftwood, 75-78.

79. "Injunction Prevents the Sale," 2, emphasis added.

80. The Coxes raised and educated Wayne's nephew George Wayne Cox and gave him a job at Mississippi Life. He worked his way up to manager of the Industrial Department, earning \$100 a month. In 1919, George arranged a secret meeting with John Merrick, one of the founders of NCMIC, and agreed to establish the company in Mississippi, which made it a direct competitor with his aunt's company. By 1923, he secured licenses for NCMIC in Mississippi and the three other states in Mississippi Life's territory, wrote \$13 million in policies, and generated an annual premium income of over half a million dollars. See mention of Cox and Merrick meeting in Andrews, John Merrick, 90 and 146-147; George's move to Indianola and positions at Mississippi Life and NCMIC in Stuart, Economic Detour, 224-225; Weare, Black Business in the "New South," 107, 113, and 131; Vann and Jones, Durham's Hayti, 89; and "[George W. Cox] Worked Way Up," Wyandotte Echo [Kan.], November 12, 1937. 
or fraternalism. ${ }^{81}$ She does not appear to have taken any meaningful role in any Mississippi colored women's club; Mississippi's black clubwomen's social reforms and institution building centered in Vicksburg and Jackson. No orphan's homes or industrial schools for delinquent girls were built in or near Indianola. The Coxes would certainly have been at the forefront, or at the very least the benefactors, of such institutions. Cox was of a different stripe than Sable Victorians, more interested in the benefits of commercial aspirations than in traditional expressions of social reform and uplift. She represents a different way for black women to be: She strengthened families and left a legacy by charging fair rents and interest rates to the more than two dozen families sharecropping on her land; providing mortgages and affordable rents to hundreds of blacks living on both sides of the tracks in Indianola and in the town's rural hinterlands; hiring blacks in respectable, white-collar positions; and paying claims to sustain families in the event of a loved one's death. ${ }^{82}$

When Mississippi Life started business in 1908, Cox's more well-known contemporary Sarah Breedlove Walker, more famously known as Madam C. J. Walker, was only just beginning to build what would eventually become a beauty culture empire. Walker had not yet rebuffed Booker T. Washington's snub at the 1912 National Negro Business League meeting with the famous washtub speech that helped crystallize a narrative of black womanhood, business ambition, activism, and uplift. Cox too was a woman of action, melding praxis and theory together as she carved out a successful business in the heart of the Mississippi Delta in the first decade of the twentieth century. ${ }^{83}$

81. Cox may have been deeply involved in church work or in a local woman's group not affiliated with the state federation or national association of Colored Women Clubs. I have not been able to find her name in the available records, but the records are sparse. I feel safe assuming that the absence of her name in several years worth of extant records of the most popular fraternals, the National Association of Colored Women correspondence and administrative records, and state conventions and histories of the largest black denominations reflect that she did not choose these common routes for black women's activism.

82. On black women's traditional activism, see Shaw, What a Woman.

83. On the last day of the National Negro Business League convention, Washington blatantly ignored repeated requests by Walker's colleague and attorney George L. Knox to recognize her from the floor. Washington's infamous snub led her to confront him ("Surely you are not going to shut the door in my face. I feel that I am in a business that is a credit to the womanhood of our race."), after which she began what became one of her most famous speeches. She shared her inspirational story of building a thriving beauty aids manufacturing and sales business in seven years from \$1.50, stating, "I am a woman who came from the cotton fields of the South. From there I was promoted to the washtub. From there I was promoted to the cook kitchen. And from there I promoted myself into the business of manufacturing hair goods and preparations" (Walker, "[Remarks]," Report of the Thirteenth Annual Convention, 154). Also see “'The Negro Woman in Business!' Mme. C. J. Walker Urges Her Sisters to Rise above the Wash Tub and Cook Kitchen to Make a Place In the Commercial World," Freeman [Indianapolis, Ind.], September 20, 1913, p. 1. 
With no letters or diaries and merely a few public records in her own hand, one must endeavor to understand Cox based on what she did rather than what she tells us. For Cox, the politics of respectability did not easily combine with the separate group economy to justify black women's participation in the "public," or more accurately commercial, sphere or to defend what Stephanie Shaw, a historian of black professional women, describes as "socially responsible individualism." ${ }^{4}$ Historian Tiffany Gill notes the difficulties black women experienced in articulating and claiming their place in black business development through "the gendered rhetoric of economics and entrepreneurship within the racial uplift ethos.”85 Minnie Cox's personal life and professional career reveal those difficulties.

The significance of individual achievement accounted for something, though one can debate how much it meant. The success and even the eventual failure of Mississippi Life celebrate Cox's hustle and business acumen but they also reveal their costs. It is important not to erase the critique of capitalism in general and the black separate economy in particular that grows organically out of the relationship between consumers and owners. Cox's relationship with the community she alternately depended on, served, and exploited reveals the precarious and fraught relationship between "black business" as "black power." Cox, her contemporaries like Maggie Lena Walker, and even her nemesis Heman Perry shared in the political, social, and economic repression borne by the masses of blacks but claimed a measure of agency that they felt distinguished them from those masses and qualified them for wider rights of citizenship. Rather than stake a claim based largely on ideologies such as comportment, moral superiority, and intellectual advantages, enterprising women like Cox undergirded class distinctions based on economic reality rather

84. The politics of respectability represented a form of resistance developed among early-twentieth-century black women activists and reformers to counteract negative stereotypes and claims about black women's sexuality, morality, and femininity. Over time, various groups adopted the politics of respectability to reject popular stereotypes and to assert their rights and privileges. According to Kali Gross, by "[c]laiming respectability through manners and morality [the politics of respectability] furnished an avenue for African Americans to assert the will and agency to redefine themselves outside the prevailing racist discourses." The politics of respectability, however, was a double-edged sword because "its ideological nature constituted a deliberate concession to mainstream societal values" (Gross, "Examining the Politics of Respectability"). In addition, it also devalued the effects of structural systemic, and institutional discrimination and disparities. Regarding socially responsible individualism, Shaw focuses on professional, not entrepreneurial, black women and describes them as balancing ambitious goals of individual achievement with a commitment to social responsibility for the community (Shaw, What a Woman, 7 and 245n2).

85. Gill, Beauty Shop Politics, 12. 
than cultural ideology. Minnie Cox's leadership of Mississippi Life after 1916 reflects the limits and the possibilities of black business operating under the limitations of an industry that marked women as dependents rather than economic agents and in a business climate marked by Jim Crow. ${ }^{86}$

\section{Bibliography of Works Cited}

\section{Books}

Andrews, R. McCants. John Merrick: A Biographical Sketch. Durham, N.C.: Seeman Printery, 1920.

Ayers, Edward L. The Promise of the New South: Life after Reconstruction. New York: Oxford University Press, 1992.

Basye, Walter. History and Operation of Fraternal Insurance. Rochester: Fraternal Monitor, 1919.

Beito, David T. From Mutual Aid to the Welfare State: Fraternal Societies and Social Services, 1890-1967. Chapel Hill: University of North Carolina Press, 2000.

Best's Life Insurance Report. Thirteenth Annual Edition, 1918-1919. New York: Alfred M. Best Company, Inc., 1918.

Browne, William W., and D Webster Davis.. The Life and Public Services of Rev. Wm. Washington Browne: Founder of the Grand Fountain U. O. of True Reformers. Richmond: M. A. Browne-Smith, 1910.

Cobb, James C. The Most Southern Place on Earth: The Mississippi Delta and the Roots of Regional Identity. New York: Oxford University Press, 1992.

Fahey, David M. The Black Lodge in White America: "True Reformer" Browne and His Economic Strategy. Dayton, Oh.: Wright State University Press; Lanham, Md.: University Pub. Associates, 1994.

Gamber, Wendy. The Female Economy: The Millinery and Dressmaking Trades, 1860-1930. Urbana: University of Illinois Press, 1997.

Gill, Tiffany M. Beauty Shop Politics: African American Women's Activism in the Beauty Industry. Urbana: University of Illinois Press, 2010.

Gilmore, Glenda. Gender and Jim Crow: Women and the Politics of White Supremacy in North Carolina, 1896-1920. Chapel Hill: University of North Carolina Press, 1996.

Gritter, Elizabeth. River of Hope: Black Politics and the Memphis Freedom Movement, 1865-1954. Louisville: University Press of Kentucky, 2014.

86. Cox spent the remainder of her days in quiet retirement. In 1925, she married George Hamilton and moved to Rockford, Illinois, where she raised her two grandsons. She returned to Indianola at least once a year to take care of her business matters. In 1928, the Delta Penny failed due to the economic depression that affected rural farming communities in the decade before the Great Depression. Minnie Cox Hamilton died in Rockford in 1933. She is buried in a modest plot in White Rock Cemetery in Indianola next to her first husband Wayne. The author thanks Indianola Postmaster Annette Turner for the location of Cox's grave. 
Hoffman, Frederick L. History of the Prudential Insurance Company of America (Industrial Insurance), 1975-1900. Newark, NJ: Prudential Press, 1900.

- Race Traits and Tendencies of the American Negro. Publications of the American Economic Association, Volume 11. New York: American Economic Association; Macmillan, 1896.

Holtzclaw, Robert Fulton. Black Magnolias: A Brief History of the AfroMississippian, 1865-1980. Shaker Heights, OH: Keeble Press, 1984.

Johnson, T. J. From the Driftwood of Bayou Pierre. Louisville: The Dune Press, 1949.

Lee, George W. Beale Street: Where the Blues Began. New York: R. O. Ballou, 1934.

Litwack, Leon F. Trouble in Mind: Black Southerners in the Age of Jim Crow. New York: Vintage Books, 1998.

Marlowe, Gertrude. A Right Worthy Grand Mission: Maggie Lena Walker and the Quest for Black Economic Empowerment. Washington, D.C.: Howard University Press, 2003.

McMillen, Neil R. Dark Journey: Black Mississippians in the Age of Jim Crow. Chicago: University of Illinois Press, 1989.

McWhirter, Cameron. Red Summer: The Summer of 1919 and the Awakening of Black America. New York: Henry Holt and Company, 2011.

Merritt, Carole. The Herndons: An Atlanta Family. Athens: University of Georgia Press, 2002.

Powdermaker, Hortense. After Freedom: A Cultural Study in the Deep South. New York: Viking Press, 1939.

Rabinowitz, Howard N. The First New South, 1865-1920. Arlington Heights, Ill.: Harlan Davidson, 1992.

Report of the Eleventh Annual Convention of the National Negro Business League, Held in New York City, N.Y., August 17-19, 1910. Nashville: AME Sunday School Union, 1911.

Report of the Seventeenth Annual Convention of the National Negro Business League, Kansas City, Missouri, August 16-18, 1916. Nashville: National Baptist Publishing Board, 1916.

Report of the Thirteenth Annual Convention National Negro Business League, Held in Chicago, Ill., August 21-23, 1912. [Nashville?]: [AmE Sunday School Union?], [1913?]

Rubio, Philip F. There's Always Work at the Post Office: African American Postal Workers and the Fight for Jobs, Justice, and Equality. Chapel Hill: University of North Carolina Press, 2010.

Shaw, Stephanie J. What a Woman Ought to Be and Do: African American Professional Women Workers During the Jim Crow Era. Chicago: University of Chicago Press, 1996.

Spectator Company. Insurance Yearbook: Life, Casualty, and Miscellaneous, Volume 45 (1916-1917). New York: The Spectator Company, 1917.

- Insurance Yearbook: Life, Casualty, and Miscellaneous, Volume 49 (1921-1922). New York: Spectator Company, 1921.

Stockley, Grif. Blood in Their Eyes: The Elaine Race Massacres of 1919. Fayetteville: University of Arkansas Press, 2001. 
Stuart, M[erah]. S. An Economic Detour: A History of Insurance in the Lives of American Negroes. New York: Wendell Malliett, 1940.

Tucker, David M. Lieutenant Lee of Beale Street. Nashville: Vanderbilt University Press, 1971.

Tuttle, William M. Race Riot: Chicago in the Red Summer of 1919. New York: Athenaeum Press, 1970; reprint, Champaign: University of Illinois Press, 2009.

Vann, Andre D. and Beverly Washington Jones. Durham's Hayti. Charleston, S.C.: Arcadia Publishing, 1999.

Walker, Juliet E. K. The History of Black Business in America: Capitalism, Race, Entrepreneurship. New York: Macmillan Library Reference USA; London: Prentice Hall International, 1998.

Weare, Walter B. Black Business in the New South: A Social History of the North Carolina Mutual Life Insurance Company. Urbana: University of Illinois Press, 1973.

Whitaker, Robert. On the Laps of Gods: The Red Summer of 1919 and the Struggle for Justice That Remade a Nation. New York: Random House, 2009.

Williamson, Joel. The Crucible of Race: Black-White Relations in the American South since Emancipation: Black-White Relations in the American South since Emancipation. Oxford: Oxford University Press, 1984.

Woodruff, Nan Elizabeth. American Congo the African American Freedom Struggle in the Delta. Cambridge, MA: Harvard University Press, 2003.

Woodward, C. Vann. The Strange Career of Jim Crow: A Commemorative Edition. New York: Oxford University Press, 2002.

\section{Articles}

Agesa, Jacqueline, Richard Agesa, and Woodrow Berry. "A History of Racial Exploitation in Life Insurance." Franklin Business and Law Journal 2011, No. 3 (September 2011): 1-21.

Butler, John Sibley and Kenneth Wilson. "Entrepreneurial Enclaves in the African American Experience." National Journal of Sociology 2 (Winter 1988): 128-166.

Crossney, Kristen and David Bartelt. "Residential Security, Risk, and Race: The Home Owners' Loan Corporation and Mortgage Access in Two Cities." Urban Geography 26, no. 8 (2005): 707-736.

Crum, Frederick S. "White and Colored Mortality Rates. Negroes Not So Long Lived as Caucasians, Comparative Tables Demonstrate. Not Entitled, Therefore, to Same Insurance Rates.” The Spectator (May 22, 1919): 77.

De Santis, Vincent P. "The Republican Party and the Southern Negro, 18771897." Journal of Negro History 45, No. 2 (April 1960): 71-87.

Gatewood, Willard B. "Theodore Roosevelt and the Indianola Affair." Journal of Negro History 53, No. 1 (January 1968): 48-50.

Gross, Kali N. "Examining the Politics of Respectability in African American Studies." [University of Pennsylvania] Almanac 43, No. 28 (April 1997). Accessed April 1, 2005. http://www.upenn.edu/almanac/v43/n28/benchmrk. html. 
McMillen, Neil R. "Perry W. Howard, Boss of Black-and-Tan Republicanism in Mississippi, 1924-1960." Journal of Southern History 48, No. 2 (May 1982): 205-224.

Mowry, George E. "The South and the Progressive Lily White Party of 1912." Journal of Southern History 6, No. 2 (May 1940): 237-247.

Scheiner, Seth M. "President Theodore Roosevelt and the Negro, 1901-1908." The Journal of Negro History 47, No. 3 (July 1962): 169-182.

Tucker, David M. "Black Pride and Negro Business in the 1920's: George Washington Lee of Memphis." Business History Review 43, No. 4 (Winter 1969): 435-451.

\section{Unpublished Works}

Bouk, Daniel. "The Science of Difference: Designing Tools for Discrimination in the American Life Insurance Industry, 1830-1930.” PhD diss., Princeton University, 2009.

Brown, Elsa Barkley. "Uncle Ned's Children: Negotiating Community and Freedom in Postemancipation Richmond, Virginia." PhD diss., Kent State University, 1994.

Bryson Jr., Winfred Octavus. "Negro Life Insurance Companies: A Comparative Analysis of the Operating and Financial Experience of Negro Legal Reserve Life Insurance Companies.” PhD diss., University of Pennsylvania, 1948.

Garrett-Scott, Shennette. "Daughters of Ruth: Black Women in Insurance in the New South, 1890s-1930s." PhD diss., University of Texas at Austin, 2011.

Pethel, Mary Ellen. "Athens of the South: College Life in Nashville, A New South City, 1897-1917.” PhD diss., Georgia State University, 2008.

\section{Encyclopedias}

Gates, Henry Louis, Jr., and Evelyn Brooks, , eds. African American National Biography. In Oxford African American Studies Center. http://www. oxfordaasc.com.

Gibson, John W., ed. Progress of a Race. New York: J. L. Nichols, 1905. Reprinted. New York: Arno Press, 1969.

Hamilton, G. P., ed. Beacon Lights of the Race. Memphis: E. H. Clarke \& Brothers, 1911.

Ingham, John N., and Lynne B Feldman., eds. African-American Business Leaders: A Biographical Dictionary. Westport, Conn.: Greenwood Press, 1994.

Mather, Frank Lincoln, ed. Who's Who of the Colored Race: A General Biographical Dictionary of Men and Women of African Descen., Vol. 1. Chicago, 1915.

Sewell, George A., and Margaret L Dwight, eds. Mississippi Black History Makers. Jackson: University Press of Mississippi, 1984.

Walker, Juliet E. K., ed. Encyclopedia of African American Business History. Westport, Conn.: Greenwood Publishing Group, 1999. 


\section{Government Publications}

Historian U.S. Postal Service. "African-American Postal Workers in the 19th Century.” Accessed April 1, 2015. http://about.usps.com/who-we-are/ postal-history/african-american-workers-19thc-2011.rtf.

Rowland, Dunbar, ed. Mississippi Department of Archives and History, The Official and Statistical Register of the State of Mississippi. Nashville: Brandon Printing, 1908.

State of Mississippi, Insurance Department. Biennial Report of the Insurance Department of the State of Mississippi from March 1, 1909, to March 1, 1911. Nashville: Brandon Printing Co., 1911.

—. Biennial Report of the Insurance Department of the State of Mississippi from March 1, 1911, to March 1, 1913. Nashville: Brandon Printing Co., 1913.

—. Biennial Report of the Insurance Department of the State of Mississippi from March 1, 1913, to March 1, 1915. Memphis: Paul and Douglass Co., [1915?].

- Biennial Report of the Insurance Department of the State of Mississippi from March 1, 1917, to March 1, 1919. Jackson, Miss.: Tucker Printing House, [1919?].

- Biennial Report of the Insurance Department of the State of Mississippi from March 1, 1919, to March 1, 1921. n.p.: s.l., [1921?].

State of Mississippi, Department of Insurance. Annual Report of the Department of Insurance of Tennessee, for the Year Ending December 31, 1921: Fire, Casualty, Life, and Fraternal, Nashville: Brandon Printing Company, 1922.

U.S. Census, 1910 and 1920. http://www.familysearch.com and http://www. heritagequest.com.

U.S. House of Representatives. Resignation of the Postmaster at Indianola, Miss., H.R. Doc. No. 422, 57th Congress, 2d Session, In United States Congressional Serial Set, Issue No. 4531, Washington: Government Publishing Office, 1903-1906.

\section{Court Cases}

Mississippi Beneficial Life Insurance Co v Leona Stephens, Case No. 21439, Mississippi Supreme Court, October Term 1920 (MDAH)

Mississippi Beneficial Life Insurance Company v Washington Oatis Jr., Guardian for Ressie [Reese] and Rex Oatis, pp. 6-7, Case 21622, Second District, Chancery Court, Jefferson Davis County, June Term, 1920 (MDAH)

\section{Newspapers and Magazines}

Black Enterprise

Broad Axe

Chicago Defender

Cleveland Gazette

Crisis Magazine

Dallas Express

Forbes

Freedman 
Hinds Gazette

Houston Informer

Independent

Memphis: The City Magazine

Negro Star

New York Age

Pittsburgh Courier

The Standard, a Weekly Insurance Newspaper

Topeka Plaindealer

Wyandotte Echo

\section{Archives}

Chancery Clerk Office, Sunflower County, Indianola, Mississippi

Mississippi Department of Archives and History, Jackson, Mississippi (мDAн) 


\section{Appendix}

Table 1 Snapshot of Black-Owned Insurance Companies Offering Whole Life Insurance, 1921, by Age

\begin{tabular}{|c|c|c|c|c|c|c|c|c|c|c|}
\hline Company & Headquarters & $\begin{array}{l}\text { Year } \\
\text { Inc'd }\end{array}$ & $\begin{array}{l}\text { Par Value } \\
\text { of Shares }\end{array}$ & $\begin{array}{c}\text { Authorized } \\
\text { Capital }\end{array}$ & $\begin{array}{c}\text { Admitted Assets } \\
\text { (Market Value) }\end{array}$ & $\begin{array}{c}\text { Whole Life } \\
\text { Insurance Cash } \\
\text { Premium Income* }\end{array}$ & $\begin{array}{c}\text { Total } \\
\text { Income** }\end{array}$ & $\begin{array}{c}\text { Net } \\
\text { Reserve }\end{array}$ & $\begin{array}{c}\text { Insurance } \\
\text { Written*** }\end{array}$ & $\begin{array}{l}\text { Insurance } \\
\text { in Force }\end{array}$ \\
\hline North Carolina Mutual & Durham, NC & 1898 & Mutual & $\mathrm{n} / \mathrm{a}$ & $\$ 1,517,922$ & $\$ 1,396,697$ & $\$ 1,632,304$ & $\$ 1,199,745$ & $\$ 22,278,902$ & $\$ 33,763,816$ \\
\hline National Benefit & Washington, DC & 1898 & NR & $\$ 100,000$ & $\$ 597,859$ & $\$ 31,896$ & $\$ 601,636$ & $\$ 374,448$ & $\$ 6,885,381$ & $\$ 10,836,337$ \\
\hline Mississippi Life & Memphis, TN & 1909 & $\$ 100$ & $\$ 100,000$ & $\$ 385,361$ & $\$ 128,215$ & $\$ 884,958$ & $\$ 253,750$ & NR & $\$ 10,204,034$ \\
\hline Standard Life & Atlanta, GA & 1911 & $\$ 100$ & $\$ 100,000$ & $\$ 1,554,424$ & $\$ 877,951$ & $\$ 1,056,676$ & $\$ 1,554,424$ & $\$ 12,513,877$ & $\$ 20,596,871$ \\
\hline Liberty Life & Chicago, IL & 1919 & $\$ 10$ & $\$ 100,000$ & $\$ 113,284$ & $\$ 5,353$ & $\$ 210,732$ & $\$ 2,272$ & $\$ 256,500$ & $\$ 254,500$ \\
\hline
\end{tabular}

Note that Liberty Life had a contributed surplus of $\$ 200,000$, which was counted in its total income.

Significant gaps in the extant records exist. However, even when records are available, key information is conspicuously absent. The Mississippi Insurance Commission's annual reports are notorious for large absences and mistakes. For example, the reports for 1913 and 1914 listed the company under industrial insurers and not legal reserve companies. Others missed basic data, such as insurance-in-force and inaccurate officers' names.

Source: Best's Life Insurance Reports upon All Legal Reserve Companies..., 1922-1923, pp. 352-353, 440-441, 471-472, 518-519, 708-710

* Includes new and renewal premiums.

** Includes whole life, industrial, disability, and other premiums; interest on dividends; profit on sale of mature bonds; and other income.

*** Includes whole life and industrial insurance. 
Table 2 Insurance in Force for Black-Owned Insurance Companies Offering Whole Life Insurance, 1915-1921

\begin{tabular}{|c|c|c|c|c|c|c|c|}
\hline Company & 1915 & 1916 & 1917 & 1918 & 1919 & 1920 & 1921 \\
\hline North Carolina Mutual & NR & NR & $\$ 11,157,472$ & $\$ 16,096,722$ & $\$ 26,534,550$ & $\$ 33,444,396$ & $\$ 33,763,816$ \\
\hline Standard Life & $\$ 1,944,910$ & $\$ 3,330,000$ & $\$ 5,174,491$ & $\$ 8,208,720$ & $\$ 13,729,169$ & $\$ 19,864,650$ & $\$ 20,596,871$ \\
\hline National Benefit & $\mathrm{n} / \mathrm{a}$ & $\mathrm{n} / \mathrm{a}$ & $\mathrm{n} / \mathrm{a}$ & $\mathrm{n} / \mathrm{a}$ & $\$ 895,703$ & $\$ 7,696,034$ & $\$ 10,836,337$ \\
\hline Mississippi Life* & NR & NR & $\$ 4,150,483$ & $\$ 6,335,625$ & $\$ 2,032,871$ & $\$ 3,345,000$ & $\$ 10,204,034$ \\
\hline Liberty Life & $\mathrm{n} / \mathrm{a}$ & $\mathrm{n} / \mathrm{a}$ & $\mathrm{n} / \mathrm{a}$ & $\mathrm{n} / \mathrm{a}$ & $\mathrm{n} / \mathrm{a}$ & NR & $\$ 254,500$ \\
\hline
\end{tabular}

All reported amounts include whole life and industrial insurance

Source: Best's Life Insurance Reports upon All Legal Reserve Companies..., 1922-1923, pp. 353, 472, 519, 710; Spectator Insurance Year Book, Life, Casualty, and Miscellaneous, 1921-1922, p. 389; Annual Report of the Commissioners of the District of Columbia, 1919, pp. 46-47.

* Mississippi Life 1917-1920 figures calculated from Spectator Insurance Year Book, and it is unclear if all lines of insurance were included. 
Table 3 Comparison of Mississippi Life with Selected Companies Operating in Mississippi, Ranked by Insurance in Force, 1921

\begin{tabular}{|c|c|c|c|c|c|c|c|c|c|c|}
\hline $\begin{array}{l}\text { Life Insurance } \\
\text { Company }\end{array}$ & Headquarters & $\begin{array}{l}\text { Began } \\
\text { Business }\end{array}$ & $\begin{array}{l}\text { Par Value } \\
\text { of Shares }\end{array}$ & $\begin{array}{c}\text { Authorized } \\
\text { Capital }\end{array}$ & $\begin{array}{l}\text { Actual to } \\
\text { Expected } \\
\text { Mortality } \\
\text { Ratio }\end{array}$ & $\begin{array}{l}\text { Admitted } \\
\text { Assets } \\
\text { (Market } \\
\text { Value) }\end{array}$ & $\begin{array}{l}\text { Whole Life } \\
\text { Insurance } \\
\text { Premium } \\
\text { Income* }\end{array}$ & $\begin{array}{c}\text { Total } \\
\text { Income** }\end{array}$ & $\begin{array}{c}\text { Insurance } \\
\text { Written*** }\end{array}$ & $\begin{array}{l}\text { Insurance } \\
\text { in Force }\end{array}$ \\
\hline Great Southern & ou & 1909 & $\$ 10$ & $\$ 50$ & 52.4 & $\$ 10,86$ & $\$ 2,789,323$ & $\$ 3,7$ & $\$ 23$ & $\$ 10$ \\
\hline Lamar & Jackson, MS & 66 & & $\$ 100$ & 41.3 & $\$ 1,698$ & $\$ 550$ & $\$ 652,883$ & $\$ 5,2$ & 2,714 \\
\hline Protective & Birmingham, AL & 1907 & $\$ 10$ & $\$ 400,000$ & 41.5 & $\$ 1,684,283$ & $\$ 405,560$ & $\$ 526,306$ & $\$ 4,692,284$ & $\$ 15,771,444$ \\
\hline Mississippi Life & Memphis, TN & 1908 & $\$ 100$ & $\$ 100,000$ & $72.8 \S$ & $\$ 385,361$ & $\$ 128,215$ & $\$ 884,958$ & NR & $\$ 10,204,034$ \\
\hline $\begin{array}{l}\text { Lincoln Reserve } \\
\text { (FKA Afro-American } \\
\text { Life Ins. Co.) }\end{array}$ & Birmingham, AL & 1912 & $\$ 10$ & $\$ 500,000$ & $88.2 \S \S$ & $\$ 838,503$ & $\$ 351,027$ & $\$ 452,948$ & $\$ 2,617,656$ & $\$ 8,238,998$ \\
\hline Cotton States & Tupelo, MS & 1911 & $\$ 5$ & $\$ 150,000$ & 33.9 & $\$ 547,088$ & $\$ 132,900$ & $\$ 262,763$ & $\$ 3,258,969$ & $\$ 7,017,594$ \\
\hline
\end{tabular}

Companies operating in similar and/or same number of states as Mississippi Life

Source: Best's Life Insurance Reports upon All Legal Reserve Companies..., 1922-1923, pp. 160-162, 263-265, 349-351, 372-374, 602-612.

* Includes new and renewal premiums.

** Includes whole life, industrial, disability, and other premiums; interest on dividends; profit on sale of mature bonds; and other income.

*** Includes whole life and industrial insurance.

$\S$ Numbers for Mississippi Life not reported. Here used numbers from Standard Life Insurance Company, the only black-owned company to have these ratios listed in the report.

$\S \S$ Higher mortality explained as follows: "The mortality rate is high because of the general high mortality on Negro risks" (374). Lincoln Reserve was a white-owned company that marketed

to a primarily black clientele. It changed its name from Afro-American Life Insurance Company to Lincoln Reserve Life Insurance Company in 1915. 
Table 4 Details of Mississippi Life Insurance Company Business, 1917-1920

\begin{tabular}{|c|c|c|c|c|c|c|c|c|c|}
\hline \multirow[t]{2}{*}{ Year } & \multirow[t]{2}{*}{ Premiums } & \multirow[t]{2}{*}{ Total Income } & \multirow[t]{2}{*}{ Claims Paid } & \multicolumn{2}{|c|}{ New Business } & \multicolumn{2}{|c|}{ Other Insurance in Force } & \multirow[t]{2}{*}{ Assets } & \multirow[t]{2}{*}{ Surplus } \\
\hline & & & & Number & Amount & Number & Amount & & \\
\hline 1917 & $\$ 194,074$ & $\$ 201,168$ & 66,785 & 49,923 & $\$ 2,180,203$ & 48,243 & $\$ 1,970,280$ & $\$ 85,832$ & $\$ 62,591$ \\
\hline 1918 & $\$ 344,145$ & $\$ 355,664$ & 127,050 & 54,546 & $\$ 3,100,895$ & 78,548 & $\$ 3,234,730$ & $\$ 149,068$ & $\$ 110,270$ \\
\hline 1919 & $\$ 544,189$ & $\$ 552,101$ & 175,509 & 69,837 & $\$ 5,952,375$ & 104,838 & $\$ 5,993,093$ & $\$ 215,903$ & $\$ 108,659$ \\
\hline 1920 & $\$ 873,477$ & $\$ 881,118$ & 324,631 & 2,740 & $\$ 2,805,750$ & 3,288 & $\$ 3,139,950$ & $\$ 206,134$ & $\$ 102,170$ \\
\hline
\end{tabular}

Source: Spectator Insurance Year Book, Life, Casualty, and Miscellaneous, 1921-1922, pp. 184, 185, 387, 389. 